\title{
Reactive iron in marine sediments
}

\author{
Donald E. CANFiEld \\ NASA-Ames Research Center, MS 239-4, Moffett Field, CA 94035, U.S.A.
}

(Received January 12, 1988; accepted in revised form December 22, 1988)

\begin{abstract}
A combined field/laboratory study has been undertaken to explore the mineralogy, concentrations and reactivity (towards sulfide) of iron in marine sediments. Also considered is the importance of bacterial Fe liberation in regulating pore-water chemistry. Two contrasting marine environments are included; one is the relatively Fe-poor FOAM site and the other is the Fe-rich sediment of the subaqueous Mississippi Delta. Results show that oxide minerals are the most important $\mathrm{Fe}$ phases in early diagenetic pyrite formation. However, viewed separately, lepidocrocite and ferrihydrite are more reactive towards sulfide than goethite and hematite. When Fe oxides are present in relatively high concentrations, dissolved sulfide is nearly absent from sediment pore waters (with concomitant high concentrations of dissolved Fe), even in the presence of active sulfide production by sulfate reduction. A combination of experimental results and diagenetic modelling shows that in some sediments pore water Fe finds it origin in the bacterial reduction of iron oxides. This seems the case even though greater amounts of $\mathrm{Fe}$ are reduced by reaction of sulfide with iron oxides. It appears that distinct microenvironments may exist in marine sediments, where, in one microenvironment, sulfide reacts with $\mathrm{Fe}$ oxides locally precipitating Fe sulfide minerals. In another, Fe reduced and solubilized by microorganisms migrates freely into solution.
\end{abstract}

\section{INTRODUCTION}

"REACTIVE IRON" MAY be defined as that fraction of iron in marine sediments which readily reacts with sulfide (a product of dissimilatory sulfate reduction) to form various iron sulfide minerals and eventually pyrite (BERNER, 1970; GOLDHABER and KAPLAN, 1974; JøRGENSEN, 1977b, 1978b; LORD and CHURCH, 1983; RAISWELL and BERNER, 1985). In some sediments the reactivity of sedimentary iron may, in fact, limit the amount of pyrite that forms (JøRGENSEN, 1978b; KARLIN and LEVI, 1985). Also, the reactivity of sulfide towards iron minerals may be an important control on pore water sulfide levels (GOLDHABER and KAPLAN, 1974; HINES et al., 1982; CANFIELD and BERNER, 1987). Evidence for this comes from many anoxic sediments where, near the sediment-water interface, the concentration of dissolved sulfide may be quite low despite active sulfide production by sulfate reduction (HINES et al., 1982; CANFIELD and BERNER, 1987; CHANTON et al., 1987).

From another perspective, bacteria have been isolated from both marine and freshwater sediments which can oxidize a host of organic substrates using ferric iron as the terminal electron acceptor (JONES $e t$ al., 1983; JONES, 1983; LOVLEY and PHILLIPS, 1986a; TUGEL et al., 1986). Iron reducing bacteria are most effective when the iron source is hydrous iron oxide phases such as ferrihydrite (JONES, 1983; LOVLEY and PHILLIPS, 1986a). Hence, the metabolic activities of iron reducing bacteria may, in part, be controlled by the chemical nature and concentrations of reactive iron oxides.

The present study was initiated to consider in detail the influence of reactive iron oxides on sediment pore-water chemistry. Using a carefully calibrated extraction scheme the depth distributions of reactive iron phases were determined at two very different localities; one the relatively iron-rich Mississippi Delta and the other, the relatively iron-poor FOAM site in Long Island Sound. Closed system incubations were used to characterize the rates of reaction between sulfide and both naturally occurring and pure iron mineral phases. Also, rates of iron liberation to pore solution were measured in the presence and absence of sulfate reduction, allowing speculation as to the origin of dissolved iron in organic-rich sediments.

\section{Site descriptions}

The FOAM site (Fig. la) is located just off of the Connecticut shore in central Long Island Sound and has been well discussed in the literature (GOLDHABER et al., 1977; ALLER, 1980a,b; BERNER and WESTRICH, 1985; KRISHNASWAMI et al., 1984). Briefly, the water depth is 9 meters, and based on ${ }^{14} \mathrm{C}$ chronologies a sodimentation rate of about $0.1 \mathrm{~cm} \mathrm{yr}^{-1}$ has been assigned (KRISHNASWAMl et al., 1984). Bioturbation and infaunal irrigation extend to about $8-10 \mathrm{~cm}$ depth (GOLDHABER et al. 1977; ALLER, 1977), below which, pore water and solid phase profiles approximate a steady state, based on the results of reaction-advection-diffusion models (GoLDHABER $\boldsymbol{e t}$ al. 1977; Westrich, 1983; BounRFAu and CANFIFI.D, 1988). Despite this steady-state behavior, from $X$-radiographs, sedimentation at FOAM may occasionally be interrupted by storm events, which resuspend surface sediment leaving laminations and occasional shell lag deposits (KRISHNASWAMI et al., 1984).

Two sites from the submarine Mississippi Delta are also included in the present study (Fig. Ib). Sta $18\left(29^{\circ} 00.0 \mathrm{~N}, 89^{\circ} 27.9 \mathrm{~W}\right)$ is located about $15 \mathrm{~km}$ northwest of the Southwest Pass discharge, and Sta 19 $\left(28^{\circ} 50.0 \mathrm{~N}, 89^{\circ} 38.0^{\circ} \mathrm{W}\right)$ is about $35 \mathrm{~km}$ southwest of Southwest Pass. The water depth at Sta 18 is 10 meters, and sediment deposits at about $2 \mathrm{~cm} \mathrm{yr}^{-1}$. This rate is assigned from the depth distribution of the anthropogenic radionuclide ${ }^{137} \mathrm{Cs}$, which is first detected $(0.56$ $\mathrm{dpm} \mathrm{g}^{-1}$; analysis courtesy $\mathrm{W}$. Graustein at Yale Univ.) in the $40-$ $50 \mathrm{~cm}$ deep layer of sediment (proceeding from the bottom to the top of the core). This may be a maximum rate due to possible sediment mixing by benthic organisms and/or storm waves. However, $2 \mathrm{~cm}$ $\mathrm{yr}^{-1}$ is reasonable when compared to ${ }^{210} \mathrm{~Pb}$-derived sedimentation rates in the same area from Shokes (1976). Sta 19 is located in 75 meters of water with a sediment accumulation rate of approximately $1 \mathrm{~cm} \mathrm{yr} \mathrm{r}^{-1}$, based on the proximity of this station to those studied by SHOKES (1976).

\section{METHODS}

\section{Sample collection}

Mississippi Delta sediment was collected in November, 1984 from gravity cores and from subcoring box cores. To a depth of $35 \mathrm{~cm}$ all chemical analysis and sulfate reduction rate measurements were performed on box core material. For greater depths gravity core sediment 

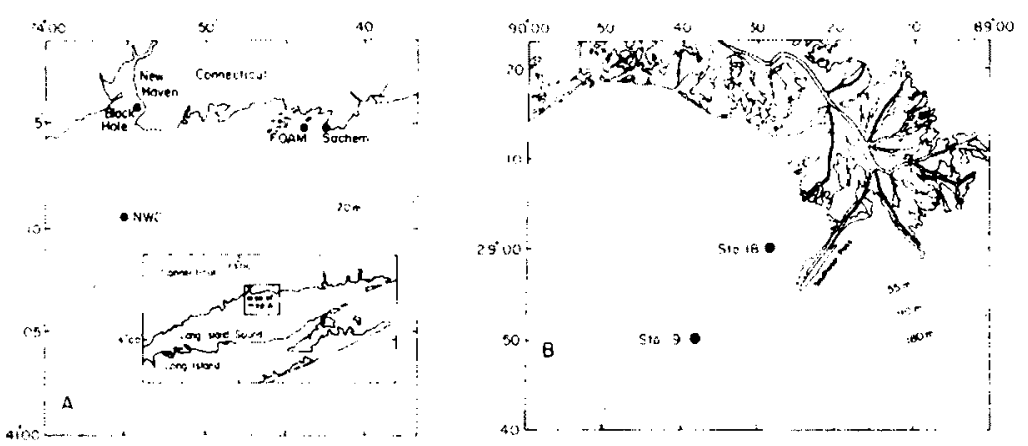

FIC. 1. Location maps for the FOAM site (Long Island Sound, USA) and Sta's 18 and 19 in the Mississippi Delta region of the Gulf of Mexico.

was used, with all pore water extractions and sulfate reduction rate measurements beginning within 12 hours of sample collection. Sediment used for incubation experiments was also collected by box coring. Sediment was scooped from the box core in $3 \mathrm{~cm}$ depth intervals and packaged into $500 \mathrm{ml}$ polyethylene bottles, which were completely filled. The bottles were placed in nitrogen filled plastic bags, which were in turn placed into another nitrogen filled bag. These samples were stored in the dark at $4^{\circ} \mathrm{C}$ for about 1 week until experiments could be started.

For the FOAM site all sediment was obtained from diver-collected box cores. Because of the close proximity of the sampling site to the lab, no sediment preprocessing was required and pore water extraction and experiments were begun within 6-10 hours of sample collection.

\section{Pore water analysis and sulfate reduction rate measurements}

For gravity core sediment core liners were cut into $10-20 \mathrm{~cm}$ lengths, capped at either end and quickly transferred into a collapsible nitrogen-filled glove bag. The clear plastic walls of box cores were ruled to the desired depths with a magic marker and the whole box core placed into the glove bag. In the glove bag sediment was collected from the core liners or the box core with a wooden spatula. The outer $1 / 2 \mathrm{~cm}$ at either end of the core liners was discarded. In all cases sediment was briefly homogenized and transferred into polyethylene centrifuge tubes, which were completely filled. Tubes were either frozen for future solid phase analysis, or centrifuged at about $\mathbf{3 0 0 0}$ pm for 10-20 minutes and returned to the glove bag. Here, pore water was extracted into plastic syringes and then filtered through $0.45 \mu \mathrm{m}$ Millipore filters.

Aliquots of filtered pore water were immediately reacted in triplicate for total dissolved sulfide (S.D. $\pm 3 \%$ ) using the methylene blue method of CuINE (1969). The detection limit for reagents used on FOAM pore water was about $0.5 \mu \mathrm{M}$, and on the Mississippi Delta cruise the available reagent had a detection limit of about $25 \mu \mathrm{M}$ Dissolved iron (S.D. $\pm 2 \%$ ) was determined on acidified (redistilled $\mathrm{HCl}$ ) pore water samples by reaction with ferrozine reagent (STOOKEY, 1970). Pore water for iron analysis was acidified immediately on removal from the glove bag and analysed within 30 days. With a 1 $\mathrm{cm}$ cell the detection limit was about $0.1 \mu \mathrm{M}$. Pore water sulfate was measured on 2-5 ml aliquots of $\mathrm{HCl}$-acidified pore water by precipitation with $\mathrm{BaCl}_{2}$, filtering, and weighing the precipitate. The precision of this analysis ranged from between $1 \%$ and $3 \%$ depending on sample size and sulfate concentration.

Sulfate reduction rates were measured at the Mississippi Delta stations using radiolabeled ${ }^{35} \mathrm{~S}_{-} \mathrm{SO}_{4}$ and the "tube" technique of JøR. GE.NSEN (1978a) and WESTRICH (1983). Incubations were terminated by freezing, and radiolabeled sulfides were collected by cold acid distillation of the frozen sediment in a $10 \% \mathrm{SnCl}_{2} / 6 \mathrm{~N} \mathrm{HCl}$ solution (WESTRICH, 1983; BERNER et al, 1979; CHANTON and MARTENS, 1985). In the mixed redox zone near the sediment surface the tube technique may either somewhat overestimate rates due to enclosing the sediment (WESTRICH, 1983) or underestimate rates because some of the produced sulfide may be oxidized by phases such as Mn oxides (J. MACKIN, pers. commun.; ALLER and RUDE, 1988). Below this zone "tube" rates are comparable with other measures of sulfate reduction such as organic carbon balance (CRILL and MARTENS, 1987) and sulfate modelling (JøRGENSEN, 1978b; WESTRICH, 1983).

\section{Solid phase analysis}

For all sites acid-volatile sulfide (AVS) was measured on frozen sediment samples using the same acid distillation as described above, followed by iodimetric titration (analytical precision 3-5\%). Total reduced sulfur (pyrite sulfur + elemental sulfur + acid volatile sulfides) was distilled from either frozen or freeze-dried sediment in a boiling chromous chloride solution (ZHABINA and VOLKOV, 1978; CANFELD et al. 1986). Even when easily oxidizable iron sulfide phases are present, all of the original reduced sulfur is still recovered using freezedried sediment (CANFIELD et al., 1986). The precision of this determination was $2-3 \%$.

Solid phase iron was divided into various fractions using a carefully calibrated extraction scheme. In developing this scheme the pure iron phases ferrihydrite, goethite, lepidocrocite, hematite, magnetite, glauconite, nontronite, almandine garnet, homblende, chlorite, and biotite were subjected to chemical leaching with a number of different reagents $(6 \mathrm{~N} \mathrm{HCl}, 1 \mathrm{~N} \mathrm{HCl}$, oxalate $\mathrm{pH}=2$ and $\mathrm{pH}=3$, hydroxylamine- $\mathrm{HCl}$, buffered acetic acid, and $\mathrm{pH}=4.8$ sodium dithionite). The silicate minerals and magnetite were obtained from the mineral collection at Yale, while hematite was obtained as a fine powder from Baker and Adamson (code \#1741). Ferrihydrite, goethite and lepidocrocite were all synthesized, with ferrihydrite prepared after SCHWERTMANN and MURAD (1983). Goethite was synthesized by aging a ferrihydrite preparation at pH 13 for 1 week at $75^{\circ} \mathrm{C}$. Lepidocrocite was prepared following SCHWERTMANN and THALMAN (1976). The purity of all minerals was checked by X-ray diffraction (ferrihydrite showed no discernible $\mathrm{X}$-ray pattern using $\mathrm{Cu} \mathrm{K}-\alpha$ radiation). The time for complete extraction of each phase was established, as well as the ability of each extractant to preferentially remove iron phases.

In brief, using freeze-dried sediment, ferrihydrite (approx. $\mathrm{Fe}(\mathrm{OH})_{3}$ ) and lepidocrocite $(\gamma \mathrm{FeOOH}$ ) were completely extracted using $0.2 \mathrm{M}$ ammonium oxalate solution (adjusted to $\mathrm{pH}=2$ ) for 2 hours at room temperature. This combination of extractant and time left goethite $(\alpha \mathrm{FeOOH})$, hematite $\left(\mathrm{Fe}_{2} \mathrm{O}_{3}\right)$ and iron-containing silicate minerals unaffected. Magnetite $\left(\mathrm{Fe}_{3} \mathrm{O}_{4}\right.$ ) is also extracted by oxalate, but was removed from all sediment samples with a strong magnet ( $\mathrm{CAN}$ FIELD and BERNER, 1987). A buffered ( $\mathrm{pH}=4.8$ for 1 hour at room temperature) citrate-dithionite solution was used to remove all of the major iron-oxide phases, while liberating only minor amounts of iron from iron-containing silicates (except nontronite, whose iron was completely extracted; see CANFIELD, 1988; and HEATH and DYMOND, 1977). Based on replicate analysis, the precision of the oxalate and dithionite extractions was about 3-4\%. Also. FOAM sediment from several depths below 2 meters (dissolved sulfide of about $6 \mathrm{mM}$ ) was used to establish "background" values for the dithionite and oxalate extractions because, at these depths, all iron oxide minerals should have reacted to form iron sulfides (see CANFELD and BERNER, 1987 , and below), and any extracted iron comes from iron contained in silicates. The background values obtained were subtracted from 
all dithionite and oxalate results. It should be mentioned that any sedimentary "amorphous" iron-containing silicates may be extracted by the "iron oxide specific" extractions mentioned above. The amount of iron bound as "amorphous" silicates in marine sediments is unknown, and as will be seen, if such phases exist they behave chemically similar to the iron oxides.

The difference between dithionitc-extracted iron and oxalate iron is termed "crystalline iron oxides" and includes the iron phases goethite and hematite. The iron distributed into sulfide phases was calculated using measured solid-phase sulfide concentrations and the appropriate stoichiometries for pyrite $\left(\mathrm{FeS}_{2}\right)$ and AVS (FeS; this assumes that greigite, $\mathrm{Fe}_{3} \mathrm{~S}_{4}$, is a minor component of AVS). On freezedrying and sitting, iron bound as acid volatile sulfides (AVS) oxidizes quantitatively to oxalate and dithionite extractable iron phases (CANFIELD, 1988). Thus, subtracting AVS-associated iron from the oxalate results gives the original sediment concentrations of lepidocrocite and ferrihydrite, which is termed "easily extractable" iron. Total iron was determined by sequential attack of sediment samples with aquaregia, $\mathrm{HF}$ and lastly $\mathrm{H}_{2} \mathrm{SO}_{4}$. For all solid phase iron determinations liquid extracts were analysed by flame atomic absorption. A complete discussion of the extraction procedure may be found in CANFIELD (1988) and CANFIELD (in preparation).

Solid phase $\mathrm{Mn}$ was extracted using $1 \mathrm{M}$ hydroxylamine- $\mathrm{HCl}$ in $25 \%$ v/v acetic acid (CHESTER and HUGHES, 1967; TESSIER et al., 1979). As recommended by TESSIER et al. (1979) an extraction time of 6 hours at room temperature was used. This procedure removes $\mathrm{Mn}$ bound in oxides, carbonates, and probably some $\mathrm{Mn}$ from silicate minerals.

\section{Iron liberation experiments}

Rates of iron liberation to interstitial solution were measured for each site in the absence of sulfate reduction, with sulfate reduction inhibited by adding $\mathrm{Na}_{2} \mathrm{MoO}_{4}$ to a final concentration of $20 \mathrm{mM}$ (SALEH $e t$ al., 1964; OREMLAND and TAYLOR, 1978; SORENSON, 1982; BANAT and NEDWELL, 1984; BANAT et al., 1983; TUGEL et al., 1986). For the Mississippi Delta sites sediment was homogenized with molybdate (in a nitrogen-filled glove bag) and packaged into 50 $\mathrm{ml}$ prepasteurized polyethylene centrifuge tubes. Each tube was sealed with a bead of silicone cement, and in groups of 10 , tubes were placed into nitrogen purged Ziplock plastic bags and completely buried in sulfide-rich salt marsh sediment (to trap any atmospheric $\mathrm{O}_{2}$ before it could reach the tubes). At appropriate times tubes were collected and pore water iron analysed. Ziplock bags were repurged with $\mathrm{N}_{2}$ before reburying.

At FOAM about $300 \mathrm{ml}$ of sediment from each sediment layer was homogenized with molybdate $(20 \mathrm{mM})$ and placed in a $600 \mathrm{ml}$ pyrex beaker. Matching petri dishes were fit to cover the sediment leaving less than a $1 \mathrm{~mm}$ gap between the petri dish and the wall of the beaker. Beakers were covered with plastic wrap and placed into a plastic bag, which was maintained within a larger glove bag under a constant flow of nitrogen gas. The time course of dissolved iron concentration was monitored by subsampling the beakers at appropriate times. For the FOAM incubations a control set of $\mathrm{HgCl}_{2}$-poisoned sediment was also monitored, as well as sulfide-rich sediment $(4 \mathrm{mM})$ from depth at FOAM to check for sulfide loss by oxidation and degassing.

\section{Unamended sediment incubations}

For all sites unaltered (no molybdate or $\mathrm{HgCl}_{2}$ ) sediment was incubated. This means that sulfate reduction was allowed to occur, and concentrations of dissolved pore water iron, sulfide, and sulfate were monitored with time. The experimental procedure for each site was the same as that described for the iron liberation experiments. A separate set of longer incubations was also run on FOAM sediment. For these incubations individual glass centrifuge tubes were filled with sediment, capped with teflon lined plastic caps, sealed with silicon cement and placed in a nitrogen atmosphere. Control tubes containing dissolved ferrous $\mathrm{Fe}$ and others containing $\mathrm{H}_{2} \mathrm{~S}$ (both at $\mathrm{pH}=7.5$ ) were also processed. Glass tubes were used because noticeable $\mathrm{H}_{2} \mathrm{~S}$ degassing was observed when sulfide-rich sediment was contained in well sealed plastic containers. All sediment incubations (including the iron liberation experiments) were conducted at $21 \pm 1^{\circ} \mathrm{C}$.

\section{Sulfide uptake experiments}

Relative rates of sulfide uptake were determined for synthetic ferrihydrite, goethite, lepidocrocite, and fine-grained reagent hematite (preparation of synthetic minerals discussed previously). In a nitrogenfilled glove bag an $11 \mathrm{mM}$ solution of $\mathrm{H}_{2} \mathrm{~S}$ at $\mathrm{pH}=7.4$ was added to about $80 \mathrm{mg}$ of each mineral in a glass centrifuge tube. The tubes were capped with teflon lined plastic caps, and after 4 hours, the reacted solutions were filtered through $0.22 \mu$ Millipore filters. Five ml's of filtrate were fixed as $\mathrm{ZnS}$ in a $3 \% \mathrm{w} / \mathrm{v}$ solution of $\mathrm{Zn}$ acetate in $10 \% \mathrm{v} / \mathrm{v}$ ammonium hydroxide. Sulfide concentration was determined by iodimetric titration. Control tubes containing sulfide solution and no iron minerals were run through an identical procedure.

\section{RESULTS}

\section{Sediment chemistry}

\section{FOAM}

Rates of sulfate reduction are presented in Fig. 2a (data from WESTRICH, 1983; and BERNER and WESTRICH, 1985), and plotted in Fig. $2 \mathrm{~b}$ are the distributions of pore water iron and sulfide obtained from summer box cores. These data are comparable to summer FOAM results reported by GOLD HABER et al. (1977) and ALLER (1980b) and similar to other anoxic marine sediments (ALLER, 1980; ELDERFIELD et al., 1981; BRICKER and TROUP, 1975; LINDSTROM, 1980; MURRAY et al., 1978; HINES and JONES, 1985). Depth distributions of solid phase acid-volatile sulfur and total reduced sulfur are shown in Fig. 2c. These data are similar to previously reported solid phase sulfur data for the FOAM site (ALLER, 1977; WESTRICH, 1983; GOLDHABER et al., 1977).

The depth distributions of iron sulfide saturation at FOAM are shown in Fig. 2d. The following equilibrium relations were used:
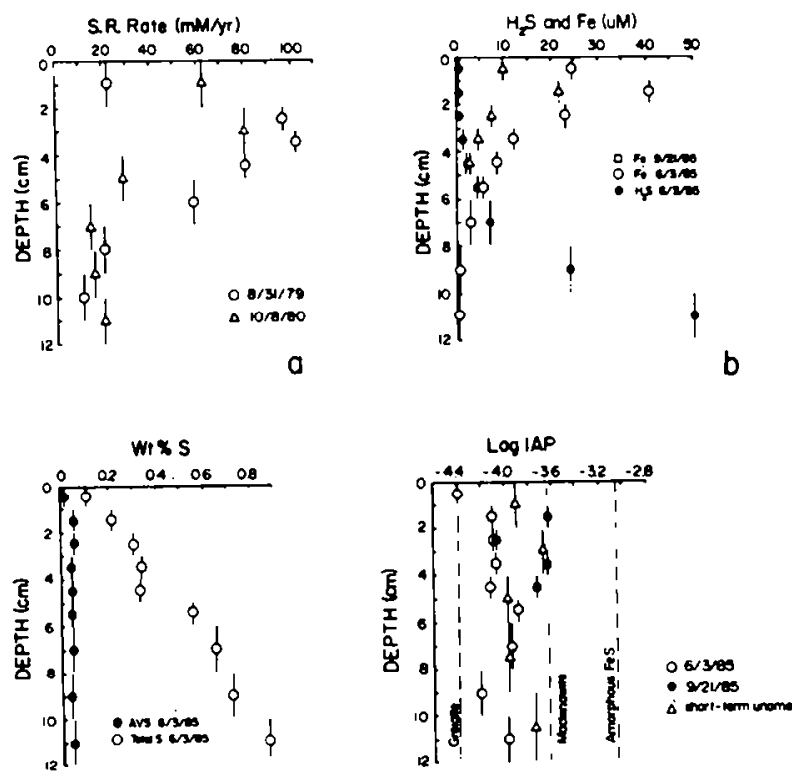

C

FIG. 2. Rates of sulfate reduction, pore water chemistry, solid phase sulfur distributions, and iron sulfide saturation for surficial FOAM sediment. In Fig. 2d IAP refers to the ion activity products for Eqns. (1) and (2) in the text. 

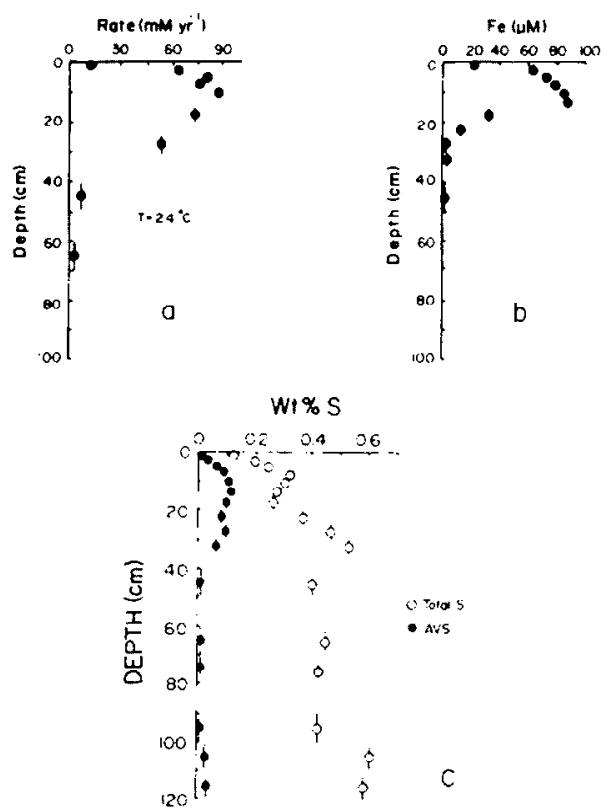

FIG. 3. Sulfate reduction rates, pore water iron, and solid phase sulfur distributions at Sta 18 in the Mississippi Delta. Dissolved sulfide is not shown because its concentration was below detection both chemically and by smell (see text for details).

$$
\begin{gathered}
\mathrm{Fe}^{2+}+\mathrm{HS}^{-} \leftrightarrow \mathrm{FeS}+\mathrm{H}^{+} \\
\mathrm{S}^{0}+3 \mathrm{Fe}^{2+}+3 \mathrm{HS}^{-} \leftrightarrow \mathrm{Fe}_{3} \mathrm{~S}_{4}+3 \mathrm{H}^{+}
\end{gathered}
$$

where FeS refers to either "amorphous" iron sulfide or mackinawite, and $\mathrm{Fe}_{3} \mathrm{~S}_{4}$ is the mineral greigite. The data from Fig. $2 \mathrm{~b}$ is combined with sediment $\mathrm{pH}(\sim 7.5$; a complete data listing can be found in CANFIELD, 1988; or is available from the author on request), equilibrium constants from EMERSON et al. (1983; recalculated from BERNER, 1967) and activity coefficients from the Davies Equation $\left(\gamma_{\mathrm{r}^{2}{ }^{2+}}=0.23\right.$; $\gamma_{\mathrm{HS}^{-}}=0.7$ ). Complexation of dissolved iron has been ignored, and for inorganic anions may not be significant (DAVISON, 1979). Organic complexation may be more important, but as yet, has not been adequately quantified (STUMM and MORGAN, 1981).

\section{Mississippi Delta sites}

Sulfate reduction rates are shown in Figs. $3 a$ and $4 a$, with dissolved pore water iron plotted in Figs. $3 b$ and $4 b$. At both Delta sites dissolved sulfide was not detected either chemically (at $>25 \mu \mathrm{M}$ to a depth of $50 \mathrm{~cm}$ ) or by smell (sensitive to a few $\mu \mathrm{M}$ ) to the full depth of coring. The depth distributions of acid volatile sulfide (AVS) and total reduced sulfur are shown in Figs. $3 \mathrm{c}$ and $4 \mathrm{c}$. Since sulfide was below detection and sediment $\mathrm{pH}$ was not measured, iron sulfide saturation could not be determined.

\section{Solid phase iron and manganese distributions}

Solid phase iron, in its various forms, is shown for all three sites in Fig. 5, with data summarized in the Appendix. Presented in Fig. 5 is the cumulative percent of total iron for the different iron phases, which factors out dilution effects such as by $\mathrm{CaCO}_{3}$. At FOAM suspended sediment was collected with a large Nisken bottle, and iron and sulfur analysis for this sediment are also presented in the Appendix. It is noteworthy that the suspended sediment contained reduced sulfur (by chromium-reduction), which is probably present as pyrite and likely has its origin in resuspended surface sediment. The results for solid phase Mn extracted by hydroxylamine- $\mathrm{HCl}$ are given in Table 1 .

\section{Unamended sediment incubations and sulfide uptake experiment}

Unamended incubations on Mississippi Delta and FOAM sediment are shown in Figs. 6 and 7, respectively. Control experiments (not shown) using sulfate free, sulfide rich FOAM sediment showed no sulfide losses. No iron or sulfide controls were run with the Mississippi Delta experiments, but due to the extreme precautions to exclude oxygen, oxidation artifacts seem very unlikely.

Results for long-term FOAM incubations are shown in Fig. 8. For most depth intervals well-defined trends in sulfate reduction rates (sulfide production rates) were not observed. This is because different rates of sulfate reduction occurred in the individual incubation tubes, resulting from the unavoidable inclusion of macrobenthos in some tubes and not in others. The utility of this data set, however, does not require well defined rates of sulfate reduction.

Results for the sulfide uptake experiment are given in Table 2. For all incubations measured dissolved sulfide concentrations are maximum values because a small amount of black FeS was observed to pass through the $0.22 \mu$ filters. This was most pronounced for the ferrihydrite and lepidocrocite incubations where, despite measurable dissolved sulfide, no sulfide was detected by smell. For the hematite and goethite incubations the amount of FeS that passed through the filters was much less. Added to the results in Table 2 is the observation that at the stan of the experiment the lepidocrocite and ferrihydrite tubes turned jet-black within 1 minute of
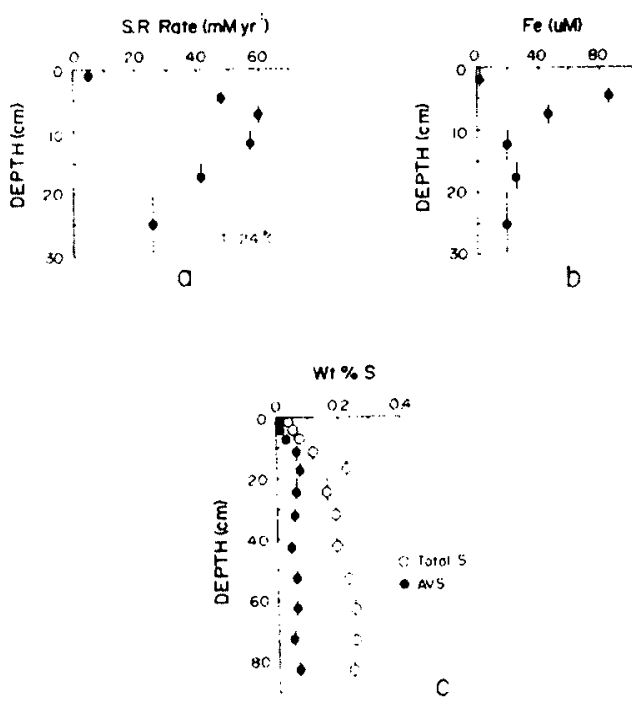

FIG. 4. Sulfate reduction rates, pore water iron, and solid phase sulfur at Sta 19 in the Mississippi Delta. As at Sta 18 the concentration of dissolved sulfide was below detection. 

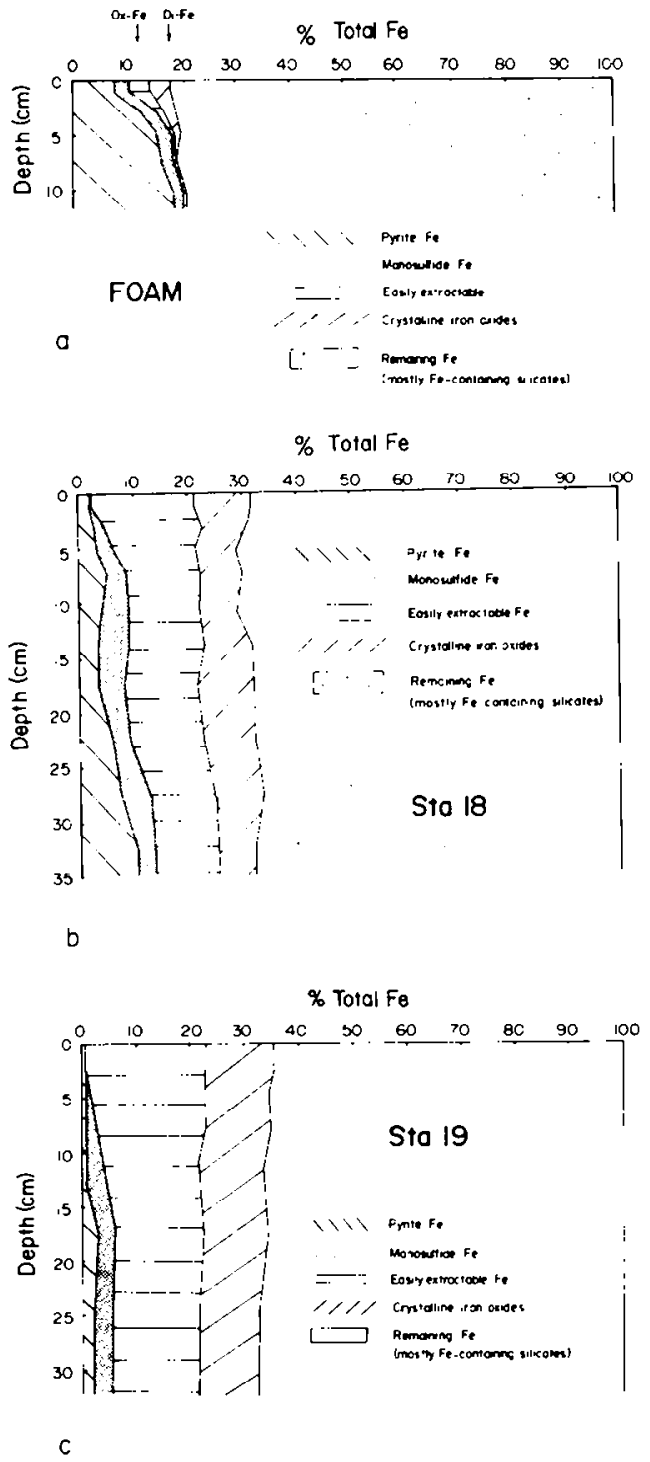

FIG. 5. Depth distributions of solid phase iron at the FOAM site and Sta's 18 and 19 in the Mississippi Delta, plotted as per cent of total iron. Each marked region represents a different iron "phase," and the width of each region (at any depth) is the per cent of total iron for a given phase.

adding the $\mathrm{H}_{2} \mathrm{~S}$ solution, whereas the hematite and goethite tubes blacked very slowly.

\section{Iron liberation experiments}

Results from the FOAM iron liberation experiments are shown in Fig. 9, and for the Delta stations, Fig. 10. In control experiments on FOAM sediment (data not shown) no inhibition of iron liberation was observed with the addition of $\mathrm{HgCl}_{2}$. However, for the 0-2 cm control experiment pasteurization at $75^{\circ} \mathrm{C}$ for 1 hour caused nearly complete inhibition of iron liberation.

\section{DISCUSSION}

\section{Field results}

Pore water and solid phase distributions may be used to explore the relative reactivities of various solid phase iron species toward sulfide and the importance of "reactive" iron in controlling pore-water chemistry. For example, in the upper sediment layers at both the FOAM site and the Mississippi Delta stations dissolved pore water iron persists, with concomitant low concentrations of dissolved sulfide, despite active sulfide production by sulfate reduction (Figs. 2, 3 and 4). At all of these stations low concentrations of dissolved sulfide are observed at depths where, based on chemical extraction results, iron oxides are present (Fig. 5). This observation reinforces the suggestion of GOLDHABER and KAPLAN (1974) that low concentrations of sulfide in surficial marine sediments may result from the rapid reaction between dissolved pore water sulfide and reactive iron minerals. Also supporting this observation is the sulfide uptake experiment (Table 2) where very rapid reaction was observed between sulfide and ferrihydrite and lepidocrocite, with significant reaction between sulfide and goethite and hematite. Similarly, PYZIK and SOMMER (1981) observed very rapid reaction between an amorphous iron oxyhydroxide (analogous to ferrihydrite) and sulfide. These authors also noted a more modest, but significant reaction rate between goethite and sulfide.

It is important that in marine sediments iron may not be the only reactive species towards sulfide. Notably, BURDIGE and NEALSON (1986) and ALLER and RUDE (1988) have documented that rapid reaction may occur between $\mathrm{Mn}$-oxides and both dissolved and solid-phase sulfides. From chemical extraction results (Table 1) elevated $M$ n concentrations, reflecting surface Mn-oxide enrichments (ALLER, 1980b; TREFRY and PRESLEY, 1982; SUNDBY and SILVERBERG, 1985), are observed in the top $2-3 \mathrm{~cm}$ at all stations. Below, concentrations stabilize to rather constant "background" values, which include $\mathrm{Mn}$ in carbonate, Mn extracted from silicates, and residual $\mathrm{Mn}$-oxides not as easily reducible as those in the surface layer. Compared to iron oxide concentrations (0.16-1 wt\%; see Appendix) the surface enrichments in $\mathrm{Mn}$ oxides $(0.01$ to $0.025 \mathrm{wt} \%$; Table 1$)$ are not large; however, depending on the relative reactivities of the different oxide phases towards sulfide, they may compete with iron for reaction with sulfide. It seems unlikely, though, that below 2$3 \mathrm{~cm}$ depth (for the sites studied here) $\mathrm{Mn}$ oxides are an important reactant for dissolved sulfide. An additional sulfidereactive species is organic carbon compounds (NISSENBAUM and KAPLAN, 1972; FraNÇOIS, 1987). However, based on the gradual enrichments in the concentration of organic sulfur with depth in anoxic sediments (FRANÇOIS, 1987) the reaction rate is apparently very slow.

At FOAM solid phase iron oxides become exhausted at about $7-10 \mathrm{~cm}$ depth (Fig. 5a), below which, the concentration of dissolved sulfide begins to increase (Fig. 2b). As men-

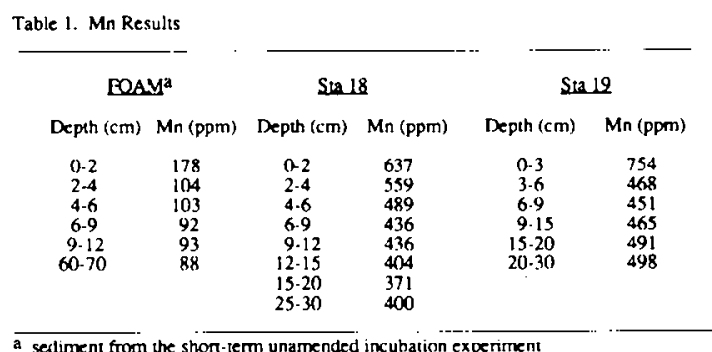



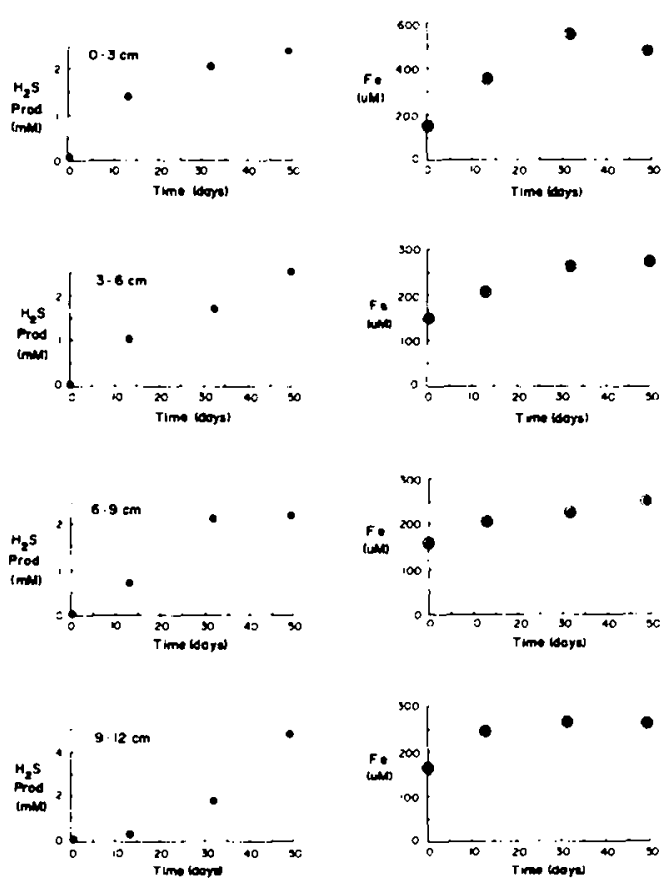

Sta 19
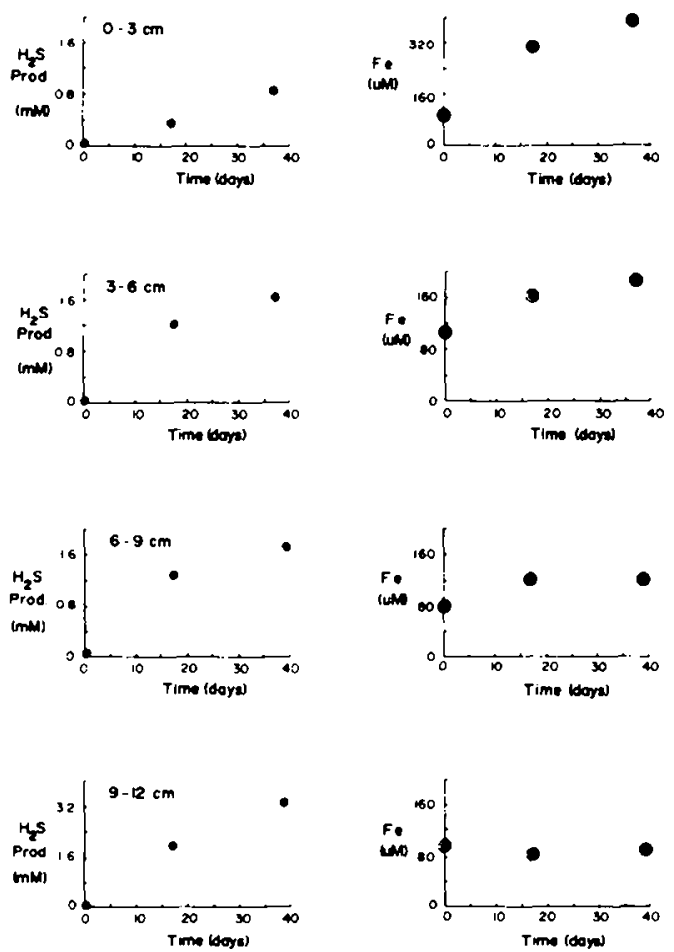

FIG. 6. Results from the unamended incubations on Mississippi Delta sediment (Sta's 18 and 19). In these experiments sulfate reduction was allowed to occur. Shown are the amounts of sulfide produced (based on sulfate deficits from original starting values) and the concentrations of dissolved iron measured in sediment pore waters as a function of time. For all depth intervals dissolved sulfide was below detection $(<0.5 \mu \mathrm{M})$
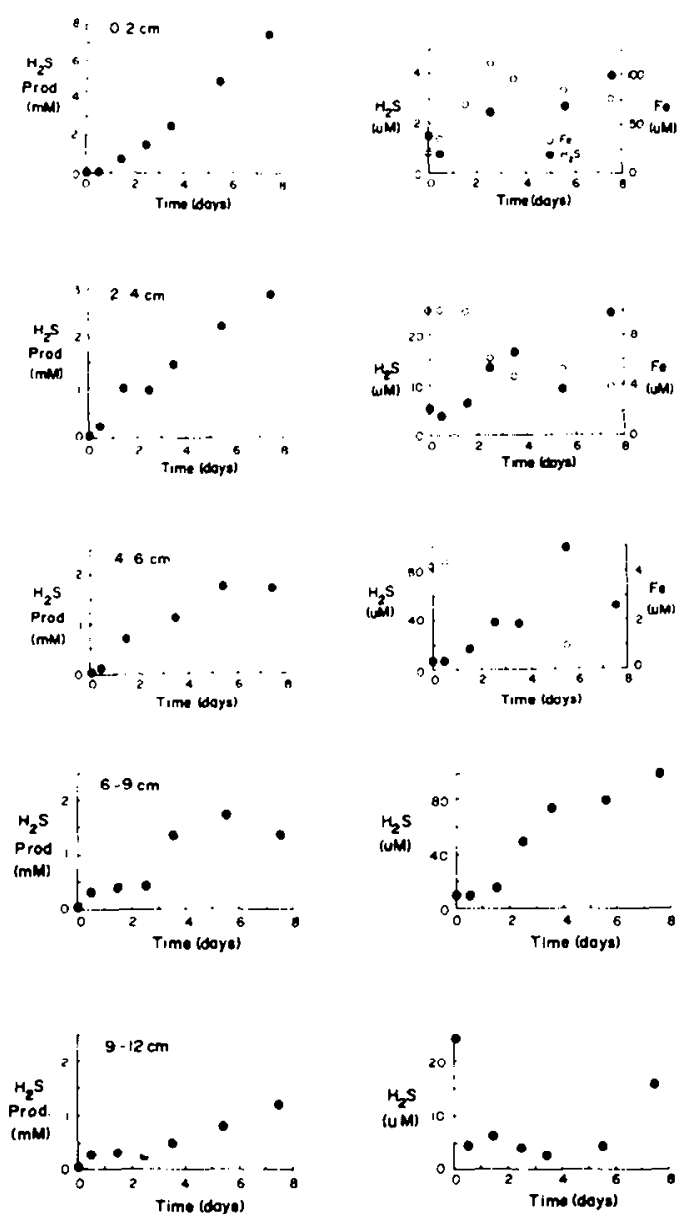

FIG. 7. Results from the short-term unamended incubations on FOAM sodiment. Shown are the amounts of sulfide producod (graphs on left, based on sulfate deficits as for the Mississippi Delta experiments), and the concentrations of dissolved sulfide and iron (graphs on right) in the sediment pore waters.

tioned, at the two Mississippi Delta stations solid phase iron oxides are present at high concentrations to the depth of sampling (Figs. 5b,c and Appendix), and dissolved sulfide was not detected either chemically at $>25 \mu \mathrm{M}$ or by smell in sediment pore waters. These results demonstrate that in marine sediments supporting sulfate reduction, the presence or absence of dissolved sulfide is a sensitive indicator as to the presence of reactive iron oxides.

At Sta's 18 and 19 sulfur-bound iron phases (pyrite + AVS) appear to form at the expense of the "easily extractable" iron oxides, which decrease in concentration with depth (Figs. 5b,c and Appendix), leaving the more crystalline iron oxides largely unaffected. This means that in a sequence of reactivity the "easily extractable" iron phases ferrihydrite and lepidocrocite are more reactive towards sulfide than the "crystalline" oxides goethite and hematite. This observation is substantiated by laboratory results (Table 2) where ferrihydrite and lepidocrocite react much faster with sulfide than goethite and hematite (see also experimental results of PYZIK and SOMMER, 1981). 
FOAM
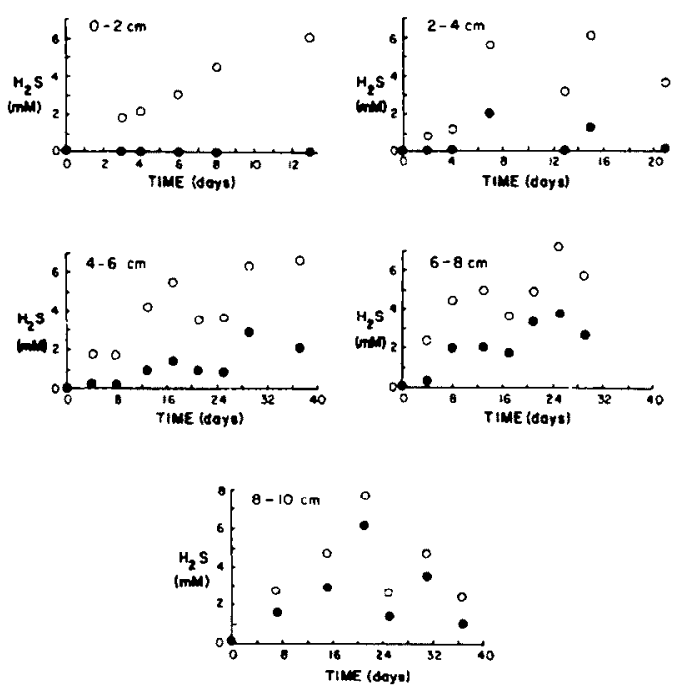

FIG. 8. Results from the long-term incubations on FOAM sediment. Filled circles are the measured concentrations of pore water sulfide during the course of the experiment. The open symbols are the amounts of sulfide produced based on the measured deficits in the concentration of pore-water sulfate.

With the complete consumption of iron oxides at FOAM by 7-10 cm (Fig. 5a) it is clear that with enough time (sedimentation rates at FOAM are 10-20 times slower than for Sta's 18 and 19) and measurable sulfide concentrations (Fig. $2 \mathrm{~b}$ ), all of the major iron oxide phases are used in early iron sulfide formation. Magnetite, a minor iron oxide component of marine sediments, persists through this zone (see CANFIELD and BERNER, 1987). From Fig. Sa the sum of oxide-iron and sulfur-bound iron remains relatively constant, perhaps increasing slightly, through the top $12 \mathrm{~cm}$. The proportion of iron bound as iron oxides and sulfides in suspended sediment, which is probably a reasonable sample of sediment depositing at FOAM, is also very similar to that found in the top 12 $\mathrm{cm}$ (see Appendix). These results suggest that at FOAM, early iron sulfides form mostly at the expense of iron oxides (supporting the suggestions of others; BERNER, 1969; GOLDHABER and KAPLAN, 1974; JØRGENSEN, 1978b), with no evidence for the substantial involvement of iron-containing silicate minerals.

\section{Unamended sediment incubations}

Short-term incubations. Sediment incubations allow the effects of sulfate reduction on sediment chemistry to be con-

\begin{tabular}{|c|c|c|}
\hline Mineral & $\underset{(\mathrm{mM})}{\text { Measured Sulfide }}$ & $\underset{(\mathrm{mM})}{\Delta \text { Sulfide }^{b}}$ \\
\hline $\begin{array}{l}\text { Fernihydrite } \\
\text { Lepidocrocite } \\
\text { Goethite } \\
\text { Hematite } \\
\text { Hematitec }\end{array}$ & $\begin{array}{l}1.92 \\
1.38 \\
8.04 \\
8.88 \\
8.70\end{array}$ & $\begin{array}{l}8.83 \\
9.37 \\
2.71 \\
1.87 \\
2.05\end{array}$ \\
\hline $\begin{array}{l}\text { Control } \\
\text { Control }\end{array}$ & $\begin{array}{l}10.80 \\
10.70\end{array}$ & \\
\hline
\end{tabular}

FOAM
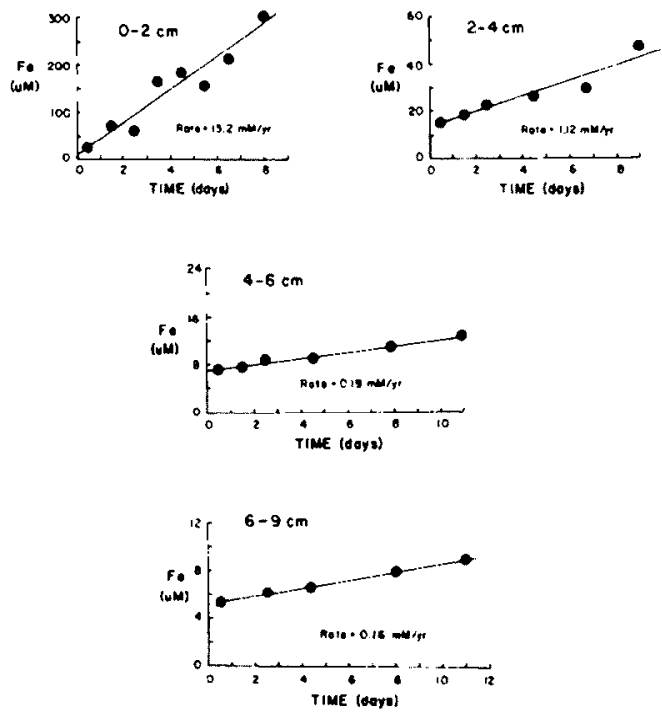

FIG. 9. Results from the iron liberation experiments on FOAM sediment. In this experiment sulfate reduction was inhibited by the addition of sodium molybdate to a final concentration of $20 \mathrm{mM}$. Incubation temperature was $21 \pm 1^{\circ} \mathrm{C}$. Presented also are the average rates of iron liberation for each depth interval.

sidered in the absence of biotubation and irrigation by benthic fauna. Organisms may complicate the interpretation of porewater chemistry by introducing bottom-water oxygen into the sediment, which, in addition to reduced iron (and manganese) phases, may also react with and oxidize dissolved and solid-phase sulfides. For the Mississippi Delta sites sediment incubations (Fig. 6) mimic the field results, where, dissolved iron was always present in high and generally increasing concentrations despite active sulfide production by sulfate reduction. In all of the incubations dissolved sulfide was undetectable at less than $0.5 \mu \mathrm{M}$. Together these observations reinforce the notion that in marine sediments the rapid reaction between dissolved sulfide and "reactive" iron oxides (and possibly Mn-oxides in the top-most sediment) effectively buffers the concentration of sulfide to low levels, allowing the build-up of dissolved iron. Such a build-up, however, may not go unchecked; at Sta 18 dissolved iron is removed from solution below $15 \mathrm{~cm}$ (Fig. 3b), and at Sta 19 , below $6 \mathrm{~cm}$. It is possible that removal occurs by saturation with and precipitation of some iron sulfide phase, especially a phase with a low solubility (such as greigite or pyrite?). Due to the low concentration of $\mathrm{H}_{2} \mathrm{~S}$ at these sites, equally possible is precipitation of non-sulfide authigenic phases such as siderite $\left(\mathrm{FeCO}_{3}\right)$ and vivianite $\left(\mathrm{Fe}_{3}\left(\mathrm{PO}_{4}\right)_{2} \cdot 8 \mathrm{H}_{2} \mathrm{O}\right.$; see MARTENS et al., 1978). Unfortunately, without $\mathrm{pH}$ values saturation with these phases could not be explored.

Short-term FOAM incubations (Fig. 7) showed that, for the first 24-48 hours after enclosing the fresh sediment, levels of dissolved sulfide stayed relatively constant and similar to starting values, even with rapid sulfide production. These results suggest that in situ at FOAM, the concentration of dissolved sulfide is controlled by the balance between sulfide production and reaction with a very reactive solid phase; likely 
Sia 18
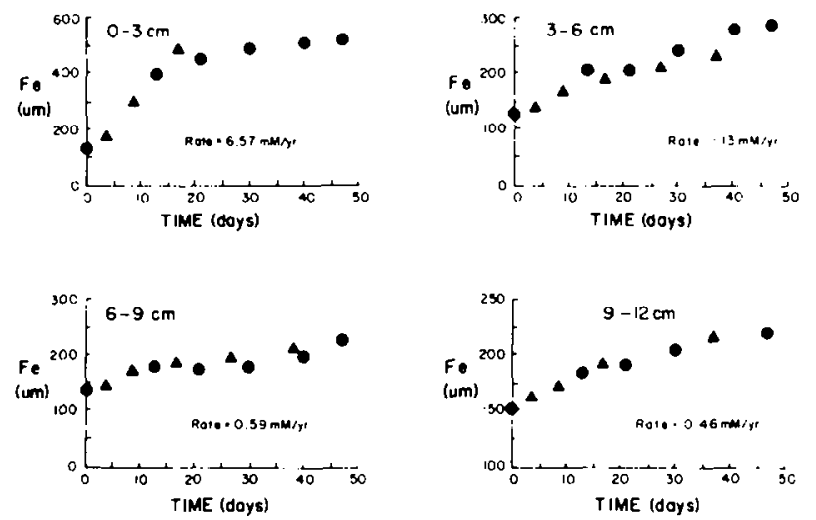

Sta 19
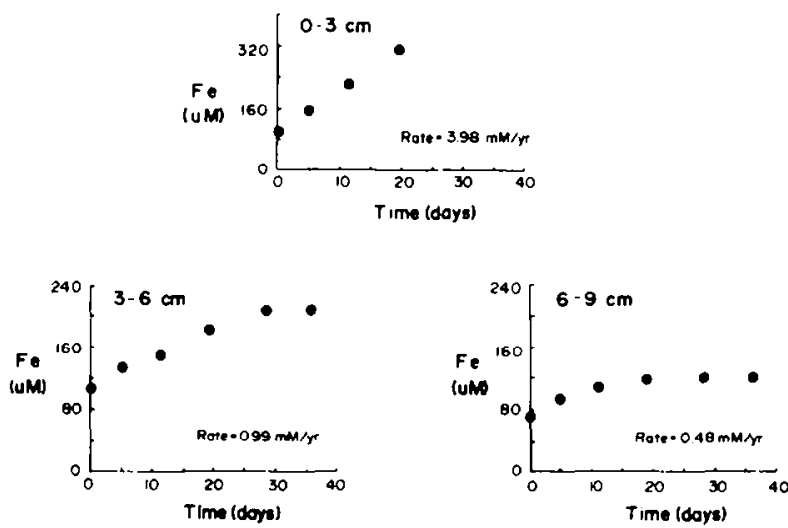

FIG. 10. Iron liberation experiments (molybdate added, no sulfate reduction) in sediment from the Mississippi Delta. For Sta $18 \mathrm{du}$ plicate experiments were performed, with the second experiment (triangles) beginning 1 week after the first (circles). Also presented are average rates of iron liberation.

a poorly crystallized iron oxyhydroxide (or Mn oxide in the top $2 \mathrm{~cm}$ ). The concentration of this reactive phase is very small and when, during the course of the experiment it becomes consumed, the concentration of sulfide builds. The new, higher, sulfide levels result from the balance between sulfide production and reaction with a less reactive iron phase. The higher sulfide levels cannot be due to simple sulfide addition to solution (by sulfate reduction), because for all depths, during the course of the experiment, 20-2000 times more sulfide was produced by sulfate reduction than was added to solution.

Similar to the Mississippi Delta incubations, for the 0-2 cm FOAM incubation dissolved pore-water iron increased at a steady rate. However, after day 2 , iron began to decrease in apparent response to rising $\mathrm{H}_{2} \mathrm{~S}$ levels. Saturation state calculations (using values from Fig. 7 and a measured sediment $\mathrm{pH}$ of 7.5) show that after day 2 dissolved $\mathrm{Fe}$ and $\mathrm{H}_{2} \mathrm{~S}$ maintained equilibrium with amorphous $\mathrm{FeS}$ (average IAP $=10^{-3.0}$, compared to $\mathrm{ksp}=10^{-3.05}$ for amorphous FeS; $\mathrm{ksp}$ values from EMERSON et al., 1983). For the 2-4 and 4-6 cm incubations dissolved iron responded to changing sulfide levels throughout the incubation, maintaining apparent saturation with mackinawite (average IAP of $10^{-3.56}$ compared to ksp of $10^{-3.64}$ for mackinawite), similar to freshly collected FOAM sediment (Fig. 2d). No iron analysis were made for the 4-6 and 6-9 cm incubations.

Long-term incubations. Similar to the short-term results, for the long-term FOAM incubations (Fig. 8) sulfide was initially reacted from solution. However, for all depth intervals below $2 \mathrm{~cm}$ sulfide reaction with the solid phase ceased, and continued sulfate reduction simply added sulfide to solution. Sulfide build-up in pore solution signaled the complete consumption of reactive iron oxide phases; at least those phases reactive on the time scale of several weeks. For the $0-2 \mathrm{~cm}$ interval reactive iron (plus reactive $M n$ oxides) was present in excess to the sulfide produced during the experiment.

If it is assumed that iron is the most important reactant for sulfide in the long-term incubations, then, with the reaction stoichiometry between solid phase iron and dissolved sulfide, the concentration of reactive iron oxides can be calculated. The reaction stoichiometry could not be directly determined; however, in controlled laboratory experiments PYZIK and SOMmER (1981) found that at near neutral $\mathrm{pH}$ the reaction between $\mathrm{H}_{2} \mathrm{~S}$ and goethite produced ferrous sulfide and elemental sulfur as the major reaction products:

$$
2 \mathrm{FeOOH}+3 \mathrm{H}_{2} \mathrm{~S} \rightarrow 2 \mathrm{FeS}+\mathrm{S}^{0}+4 \mathrm{H}_{2} \mathrm{O} .
$$

Subsequent reaction between elemental sulfur and iron monosulfides to produce pyrite does occur in marine sediments, but is probably slow on the time scale of the present sulfide uptake experiments (BERNER, 1970). The concentrations of reactive iron oxides are approximated, then, by combining the reaction stoichiometry from Eqn. (3), with sediment water content and sulfide deficits using the following formulation:

$\mathbf{w t} \% \mathrm{Fe}=\left[\Delta \mathrm{S} \times\left(\right.\right.$ mass $\left._{\mathrm{s}, 1} / \mathrm{mass}_{\mathrm{sold}}\right)$

$$
\left.\times 1 / \rho_{\text {sol }} \times 2 / 3 \times 55.9\right] 100
$$

where:

$$
\begin{aligned}
w t \% \mathrm{Fe}= & \text { weight per cent reactive iron in FOAM } \\
& \text { sediment } \\
\mathrm{mass}_{\text {sol }} / \mathrm{mass}_{\text {sold }}= & \text { mass of pore water in grams, per gram of } \\
& \text { solid } \\
\Delta \mathrm{S}= & \text { difference between the concentration of } \\
& \text { sulfide measured in solution and that ex- } \\
& \text { pected based on sulfate deficits (units of } \\
& \text { moles } \mathrm{cm}^{-3} \text { of solution) } \\
\rho_{\text {sol }}= & \text { density of pore water at } 20^{\circ} \mathrm{C}, \text { approxi- } \\
& \text { mated as } 1 \mathrm{~g} \mathrm{~cm} \mathrm{~cm}^{-3} \\
2 / 3= & \text { factor (from Eqn. } 3 \text { ) converting moles of } \\
& \mathrm{H}_{2} \mathrm{~S} \text { consumed to moles of Fe reacted } \\
55.9= & \text { molecular weight of Fe. }
\end{aligned}
$$

The results from several long-term incubations are shown in Fig. 11, with the depth distribution of reactive iron comparable to extraction results (Fig. 5a and Appendix). This similarity is encouraging and strongly suggests that chemical 


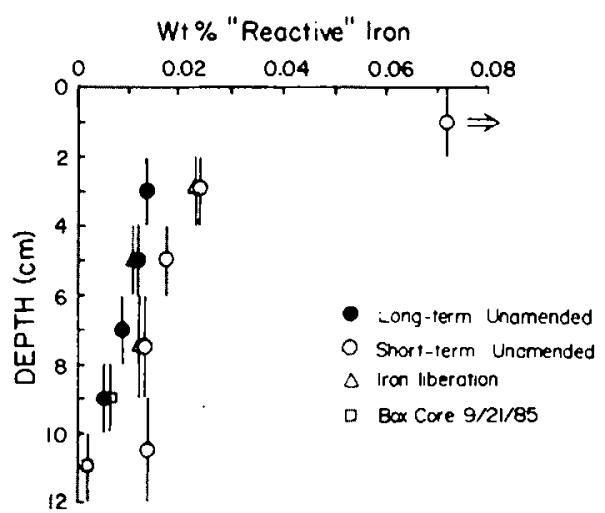

FIG. 11. The distribution of "reactive iron" with depth at the FOAM site calculated from the experiments described in Fig. 8 (see text for calculation details).

extractions can quantitatively extract sulfide-reactive iron oxide phases.

\section{Iron oxide rejuvination}

An interesting issue is the dynamic nature of iron phases in surficial marine sediments. From the sulfate reduction rates in Fig. $2 a$ and the iron oxide concentration data in the Appendix, iron oxides in the $0-2 \mathrm{~cm}$ depth interval at FOAM should be completely converted to iron sulfides in about 1 year. For sediment between $2-12 \mathrm{~cm}$ depth complete conversion would take between 2-6 weeks. The upper $12 \mathrm{~cm}$ represents 100 years of deposition, so, to maintain any reactive iron oxides it is necessary to cycle iron rapidly between reduced (sulfide) and oxidized (oxide) phases. Such cycling is driven by benthic organisms, which, through sediment burrowing and irrigation mix oxidants (such as oxygen and Mn oxides) into the sediment, oxidizing iron sulfides (ALLER, 1980a,b; ALLER and RUDE, 1988). Appreciable sulfide oxidation at FOAM is consistent with the sulfur mass-balance of BERNER and WESTRICH (1985) who calculate that in the top $12 \mathrm{~cm}$ about $90 \%$ of the sulfide produced by sulfate reduction is oxidized and lost from the sediment. At the Delta sites considerable sulfide oxidation also occurs, with about $70 \%$ of the sulfide produced by sulfate reduction at Sta 18 becoming reoxidized and about $90 \%$ at Sta 19 . So, for all sites, sulfide oxidation is important in rejuvenating iron oxides, which in turn exerts an important control on pore-water chemistry. ALLER et al. (1986) report that sediment disturbance may also be important in affecting pore-water chemistry in Amazon inner-shelf muds.

\section{Iron liberation and the origin of pore-water iron}

For all sites iron liberation to pore solution was observed in the absence of sulfate reduction (Figs. 9 and 10, and also results from SøRENSEN, 1982; JONES et al., 1983; TUGEL $e t$ al., 1986; ALLER et al., 1986; LovLEY and PHILLIPS, 1986a,b). In marine and freshwater sediments where sulfate reduction is either lacking or inhibited, iron may be liberated to solution from the bacterial reduction of iron oxides. Evidence for this comes from the inhibition of iron liberation by bacterial poi- sons (BRomfield, 1954; JoNES et al., 1983; TUGEl et al., 1986), by sediment pasteurization (BROMFIELD, 1954; SøRENSEN, 1982; JONES, 1983; JONES et al., 1983), and the fact that pure cultures of iron reducing bacteria are isolated from a wide range of anoxic marine and freshwater sediments (LOVLEY and PHILLIPS, 1986a,b; JONES et al., 1983; TUGEL et al., 1986).

In the present study the poison $\mathrm{HgCl}_{2}$ did not inhibit iron liberation in FOAM sediment; however, sediment pasteurization of FOAM 0-2 cm sediment for 1 hour at $75^{\circ} \mathrm{C}$ dramatically reduced iron liberation rates. Reduced rates were observed even though, as a result of pasteurization, dissolved organic carbon concentrations rose from $70 \mathrm{mg}^{-1}$ to 750 $\mathrm{mg} \mathrm{l}^{-1}$. This demonstrates that substantial iron liberation to pore solution may not result from reaction between ambient dissolved organic compounds and iron oxides as suggested by BERNER (1969). The pasteurization results, then, support a bacterial control on iron liberation, whereas the ineffectiveness of $\mathrm{HgCl}_{2}$ would not. This discrepancy could result from the possible removal of $\mathrm{Hg}$ from solution as a metal sulfide precipitate or the reduced efficiency of $\mathrm{HgCl}_{2}$ as a bacteriacide in the presence of high concentrations of organic compounds (PELCZAR and REID, 1965). Hence, although not unambiguously demonstrated, from the present pasteurization results and the results of others, bacterial iron reduction seems the most likely source for dissolved iron in sediments where sulfate reduction is absent.

Measured rates of iron liberation (Figs. 9 and 10) for both the Mississippi Delta sites and FOAM are a strong function of depth. (Note that the term iron liberation is used instead of iron reduction because some of the iron reduced in these experiments may adsorb onto sediment particles, causing a potential underestimate of actual iron reduction rates). At FOAM rates range between $13.2 \mathrm{mM} \mathrm{yr}^{-1}$ in the surface sediment layer $(0-2 \mathrm{~cm})$ to $0.16 \mathrm{mM} \mathrm{yr}^{-1}$ by $6-9 \mathrm{~cm}$. For the Delta sites, over a similar depth interval, rates vary by about a factor of ten, with surface rates similar, but somewhat lower than at FOAM. The reduced rates below about $4 \mathrm{~cm}$ at FOAM probably result from a lack of reducible ferric iron oxides (Figs. 5a, 11, and Appendix). The strong depth dependence of iron liberation rates at the Delta sites is not as clear, as by chemical extraction, abundant "easily extractable" iron oxides are present (Figs. 5b,c, and Appendix). LOVLEY and PHILLIPS (1986b) also observed very little iron reduction at depths in freshwater sediments where oxalate extractable iron oxides were still available. At Sta's 18 and 19 sulfate reduction rates remain relatively high through the top $12 \mathrm{~cm}$ suggesting that metabolizable organic substrate is available. It could be that differences in iron mineralogy exist that are not reflected in the extraction results. For example, the oxalate extraction cannot distinguish ferrihydrite from lepidocrocite and says nothing of grain size. Also possible is that other bacterial populations outcompete iron reducing bacteria.

For all incubations on Mississippi Delta sediment, and for the $0-2 \mathrm{~cm}$ depth interval at FOAM, rates of iron liberation are similar in the presence and absence of sulfate reduction (due to low concentrations of reactive iron below $2 \mathrm{~cm}$ at FOAM, sulfide and not iron accumulated in the unamended sediment incubations). This is shown in Fig. 12 where rates 


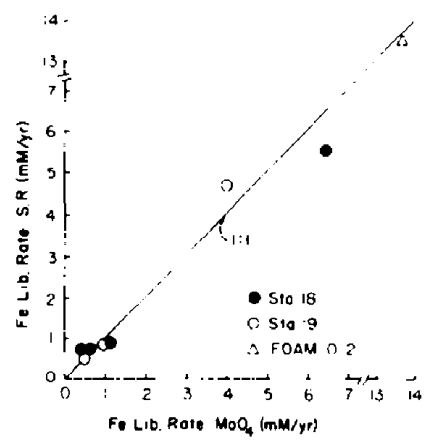

FIG. 12. Rates of iron liberation in the presence of sulfate reduction (Figs. 6 and 7) compared to the rates in the absence of sulfate reduction (Figs. 9 and 10). Data is from Sta's 18 and 19, and the $0-2 \mathrm{~cm}$ depth interval at FOAM.

of iron liberation in the absence of sulfate reduction are plotted $v s$. rates in the presence of sulfate reduction (data from Figs. 6, 7, 9 and 10). It would seem, then, that in surficial marine sediments with abundant reactive iron, the dissolved iron that accumulates in the presence of sulfate reduction (Figs. 2b, 3b and 4b) may be of the same origin as that produced when sulfate reduction is inhibited; in other words, likely from bacterial iron reduction.

This argument is complicated by the fact that in the unamended sediment incubations iron reduction also occurred by reaction of sulfide with iron oxides. The amount of oxidized iron reduced by sulfide in the short-term unamended sediment incubations is computed using the reaction stoichiometry in Eqn. (3) and assuming iron oxides are the only reactant for sulfide. In Table 3 these results are compared to the amount of dissolved iron that actually migrated into solution. It is clear that iron reduction is dominated by reaction with sulfide and hence, it becomes difficult to imagine dissolved iron as originating by another means. Required, however, is that the trend in Fig. 12 (see also SøRENSEN, 1982; and TUGEL et al., 1986) is only fortuitous, which also seems unlikely.

These apparently disparate results can be reconciled by allowing that distinct microenvironments exist in marine sediments (e.g. EMERY and RITTENBURG, 1952; JøRGENSEN, 1977a; JAHNKE, 1985), where, in one microenvironment the iron reduced by microorganisms migrates freely into solution. In another, the sulfide produced by sulfate reduction reacts with iron oxide minerals, reducing iron which is immediately precipitated as FeS by another sulfide ion (essentially Eqn. 3). This explanation is speculative and should perhaps be viewed as a working hypothesis. However, the existence of microenvironments in marine sediments does not seem unreasonable in that competition must certainly exist between bacterial populations for organic substrate, and in the case of iron reducing bacteria, for oxidized iron surfaces (TUGEL et al. 1986; JONES et al., 1983; MUNCH and OTTOW, 1982).

\section{Pore-water iron model}

It is suggested above that in some anoxic marine sediment pore waters dissolved iron originates from iron liberation reactions which are likely mediated by bacteria and unrelated

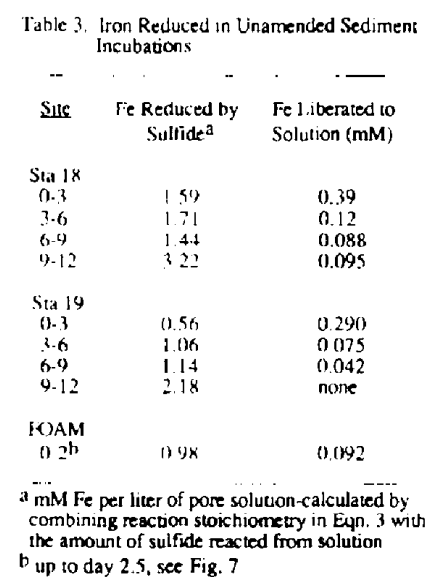

to sulfide reaction with iron minerals. This assertion is tested by predicting iron profiles from iron liberation rate data and comparing to the actual iron profiles. Pore-water iron profiles may be predicted using the following diagenetic expression (see BERNER, 1980):

$$
d C / d t=D \partial^{2} C / \partial x^{2}-\omega \partial C / \partial x+R
$$

where:

$C=$ concentration of dissolved iron $\left(\mathrm{mM} \mathrm{l}^{-1}\right)$

$l=$ time (years)

$D=$ sediment diffusion coefficient for iron

$\omega=$ sediment burial rate $\left(\mathrm{cm} \mathrm{yr}^{-1}\right)$

$x=$ sediment depth $(\mathrm{cm})$ positive downwards

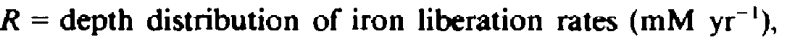
which is given by:

$$
R=A e^{-m_{1} x}+B e^{-m_{2} x}
$$

with values of $A, B, m_{1}$ and $m_{2}$ given in Table 4 (the double exponential is used to obtain a better fit to the iron liberation data).

The model neglects compaction and precipitation of iron above what may have occurred during the course of the iron liberation experiments. Adsorption is also not written into the equation. The effect of adsorption is to divide the diffusion coefficient $D$ in Eqn. (5) by the term $1+K$ (BERNER, 1980), with $K$ the adsorption constant for iron ( $R$ is not divided by $1+K$ because measured iron liberation rates are net rates of addition to pore solution and as such, have already been modified by adsorption). Unfortunately no $K$ values for iron have been measurad for marine sediments. If steady-state diagenesis is assumed, then, $d C / d t=0$. Modelling will only be attempted at Sta's 18 and 19 because at FOAM, the iron

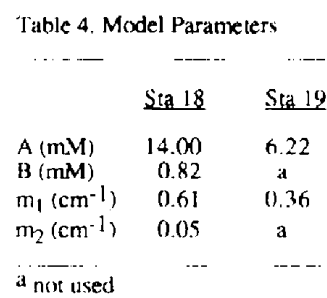




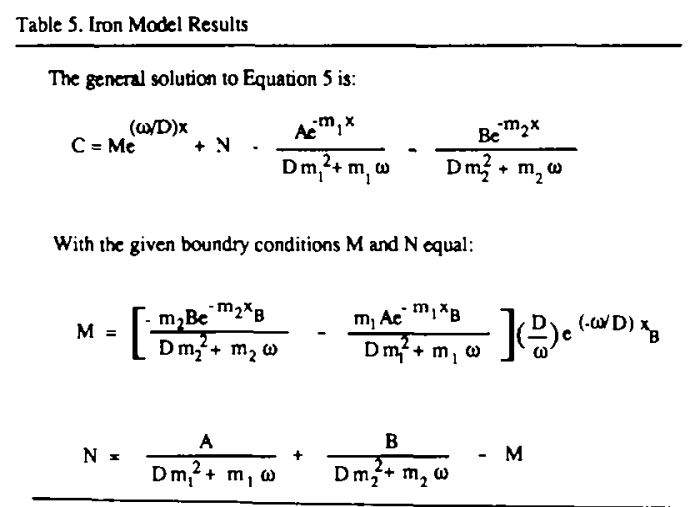

liberation experiments are at too course an interval for a reasonable prediction of the dissolved iron profile. Also, it is important that the iron liberation experiments were incubated at nearly the same temperature as ambient Mississippi Delta sediment at the time of collection $\left(21 \pm 1^{\circ} \mathrm{C}\right)$.

Equation (5) is solved using the upper boundary condition that at $x=0, C=0$ and the lower condition that at $x=x_{\mathrm{B}}$, $d C / d x=0$, with $x_{\mathrm{B}}$ taken as the depth of the iron maximum. The solution is given in Table 5 which, in principle, can be used to directly predict a unique iron profile with given sediment parameters (sedimentation rates, etc.) and iron liberation rates. However, bioturbation, faunal irrigation, and sediment disturbance by waves may all enhanced the transport of solutes into the sediment (ALLER, 1980b; BERNER, 1980), making the simple diffusion model (Eqn. S) inappropriate. The importance of enhanced solute transport is quantified by constructing a sulfur mass balance for these sites.

The simplest mass balance approach is to view the surface layer of sediment as a box, with the rate of sulfate input to the box, diffusion plus pore water burial, balanced by sulfur outputs which include the burial of reduced solid-phase sulfur, pore-water sulfate and diffusion out. Mathematically:

$$
\begin{aligned}
& \phi \omega C_{1}+\phi D d C_{1} / \mathrm{dx} \\
& \quad=\phi \omega C_{2}+(1-\phi) \omega \rho_{s c d} C_{s}+\phi D d C_{2} / d x
\end{aligned}
$$

where $\phi$ is the average sediment porosity in the layer of interest (this is a simplifying assumption as, one should include the effects of porosity changes on $\omega$ and $D$ through the layer, but for the sites here, data on $\omega$ is not good enough to make such inclusion possible), $D$ is the sediment diffusion coefficient for sulfate, $C_{1}$ and $C_{2}$ are the concentrations of sulfate at the top and bottom of the layer, with $d C_{1} / d x$ and $d C_{2} / d x$ the concentration gradients at the top and bottom (sulfate data can be found in CANFIELD, 1988), $\rho_{\text {sed }}$ is the density of solids (assumed to equal $2.5 \mathrm{~g} \mathrm{~cm}^{-3}$ ), $C_{s}$ is the concentration of solid phase sulfur at the base of the layer and $\omega$ is the sediment burial rate.

For Sta's 18 and $19 d C_{2} / d x=0$ at about $35 \mathrm{~cm}$, so, this is a convenient depth to choose for the base of the layer. The values supplied to Eqn. (7) and model results are summarized in Table 6. For Sta 19 the box is fairly well balanced; in other words, little or no solution transport above molecular diffusion occurs. This conclusion may appear at odds with the observation of appreciable sulfide oxidation at Sta 19, which probably occurs by the mixing of oxidants into the sediment. The present mass balance does not preclude this, it only requires that the mixing process operates at a rate slower than molecular diffusion.

By contrast, at Sta 18 the transport of pore water must be considerably enhanced. The nature of the enhanced transport mechanism(s) is not well known and may include bioturbation and faunal irrigation (ALLER, 1980a), sediment "pumping" caused by passing waves (HARRISON et al., 1983), or sediment stirring by waves. Because of this ignorance, the simplist approach is to describe the enhanced transport as an enhanced diffusion (for example, BERNER, 1980; VAN. DERBORGHT et al., 1977). An enhanced diffusion coefficient of about $900 \mathrm{~cm}^{2} \mathrm{yr}^{-1}$ is calculated by balancing the input and output sulfur fluxes with diffusion into the layer.

Dissolved iron profiles are generated for Sta's 18 and 19 using a number of different diffusion coefficients with results presented in Fig. 13. For both sites, iron profile predictions based on "best estimate" diffusion coefficients overestimate the actual measured concentrations of dissolved iron by a factor of 2-3 (this discrepancy would be enhanced if appreciable $\mathrm{Fe}$ adsorption occurs). The difference between measured and predicted iron profiles could result from a number of causes including overestimate of iron liberation rates in lab experiments, inaccurate description of sediment mixing (alternative descriptions are given in ALLER, 1980a; EMERSON et al., 1984; BOUDREAU, 1984), non-steady-state behavior, or dissolved iron removal not observed in the iron liberation experiments. The important point, however, is that easily enough iron is produced by iron liberation reactions (likely bacterially mediated) to account for all of the dissolved iron in Mississippi Delta pore waters.

Of course, other sources do exist for dissolved iron in marine sediment pore waters. ALLER (1980b), for example, has documented that high concentrations of dissolved iron, in association with low sediment $\mathrm{pH}$, may result from iron sulfide oxidation. In this case the oxidation occurs as the sediment redox boundary moves deeper in winter months. Only the sulfide, however, is completely oxidized; some of the dis- 

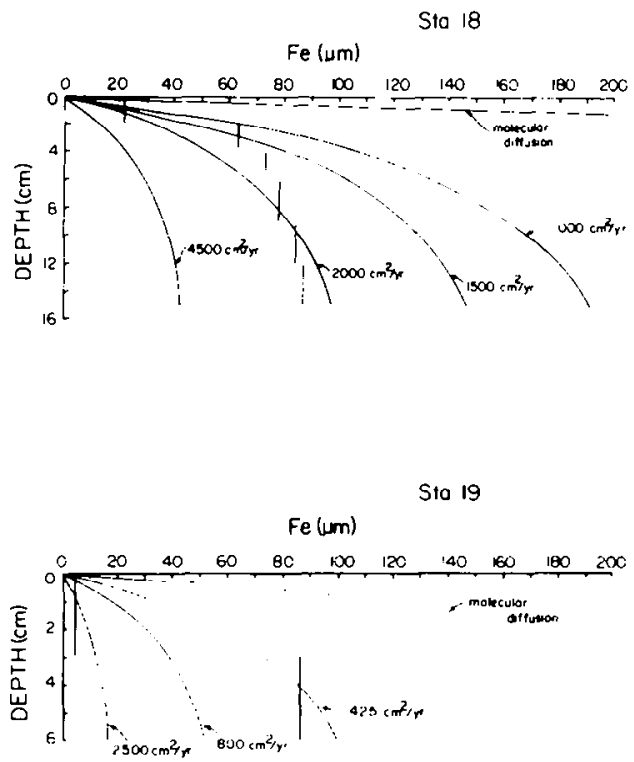

FIG. 13. Results from the iron model compared to actual sediment data (vertical bars). Shown are predicted iron profiles using different values for an "enhanced" diffusion coefficient. For molecular diffusion, a sediment diffusion coefficient for iron of $150 \mathrm{~cm}^{2} \mathrm{yr}^{-1}$ was used.

solved ferrous iron escapes oxidation and accumulates in the sediment pore waters. I observed high dissolved iron concentrations (near millimolar) and low sediment pH (6-6.5) at the Sachem site in Long Island Sound (see WESTRICH, 1983) the day after Hurricane Gloria passed through. Presumably iron sulfide oxidation and dissolved iron accumulation were related to surficial sediment mixing with the overlying water. One week prior to Gloria and two weeks after, sediment profiles of iron ( $80 \mu \mathrm{M}$ maximum) and $\mathrm{pH}$ (7.5) were "normal." From the iron oxide "residence times" discussed earlier, and the results of others (JøRGENSEN, 1977b; BERNER and WESTRICH, 1985), sulfide oxidation is probably an important year-round phenomena, and does not result solely from episodic sediment disturbance and seasonal fluctuations in the sediment redox boundary. It appears that most of the time, iron sulfide oxidation leads to iron oxide formation, and high concentrations of dissolved iron (with associated low $\mathrm{pH}$ ) accumulate only when the oxidation event is unusually pervasive.

\section{CONCLUSIONS}

In marine sediments, the availability of sediment-contained reactive iron oxide minerals can have profound effects on sediment pore water chemistry. For example, reactive iron oxides can effectively buffer the concentration of pore water sulfide to very low levels, even in the presence of active sulfate reduction. Also, the presence of dissolved sulfide in sediments indicates that reactive iron has become consumed. Evidence for this comes from the FOAM site where, at the depth where extractable iron phases become exhausted, the concentration of dissolved sulfide begins to rise. At the Mississippi Delta sites reactive iron oxides are present in high concentration and no dissolved sulfide is observed in sediment pore waters, despite high rates of sulfate reduction. For all sites studied continued reoxidation of iron sulfide minerals by benthic fauna and other physical means (waves, for example) constantly replenishes iron oxides. Without this replenishment, all of these stations would be considerably more "sulfidic."

From solid-phase sediment extraction results, early pyrite forms almost exclusively from iron oxides, with little evidence for the involvement of silicate minerals. In addition, experimental results and extraction results from the Mississippi Delta stations show that iron oxides may be subdivided, with ferrihydrite and lepidocrocite more reactive towards sulfide than hematite and goethite.

From sediment incubations and diagenetic modelling, the bacterial reduction of ferric iron may be the most important source of dissolved pore water iron in near-shore marine sediments (and probably deep-sea sediments as well; see FroF. LICH et al. 1979). This is somewhat surprising as most ferric iron is reduced by the reaction between sulfide and ferric iron oxides. It may be that microenvironments exist in sediments where, in one microenvironment the iron reduced by sulfide immediately reacts with another sulfide ion to form an insoluble iron sulfide mineral. In a separate microenvironment the iron reduced by bacteria is free to migrate into solution.

Acknowledgements-The author wishes to acknowledge the suppon and guidance of his thesis committee; Danny Rye, K. K. Turekian, Tony Lasaga, and Marty Goldhaber, with special thanks to my advisor, R. A. Berner. Also acknowledged are the very helpful comments of J. Mackin, R. Aller, and two anonymous reviewers. Support was provided by NSF grants OCE 8219580 and OCE 8508472 (to R. A. Berner).

Editorial handling: R. C. Aller

\section{REFERENCES}

ALLER R. C. (1977) The influence of macrobenthos on chemical diagenesis of marine sediments. Ph.D. dissertation, Yale University. New Haven, Conn., 600p.

Al.1.ER R. C. (1980a) Diagenetic processes near the sediment-water interface of Long Island Sound. I. Decomposition and nutrient element geochemistry. In Estuarine Physics and Chemistry: Studies in Lung Island Sound (ed. B. SALTZMAN), pp. 237-350. Advances in Geophysics Vol. 22. Academic Press.

ALLER R. C. (1980b) Diagenetic processes near the sediment-water interface of Long Island Sound. II. Fe and Mn. In Estuarine Physics and Chemistry: Studies in Long Island Sound (ed. B. Sal.TZMAN), pp. 351-415. Advances in Geophysics Vol. 22. Academic Press.

AI.LER R. C. and RUDE P. D. (1988) Complete oxidation of solid phase sulfides by manganese and bacteria in anoxic sediments. Geochim. Cosmochim. Acta 52, 751-765.

ALI.F.R R. C., MACKIN J. E. and COX R. T. (1986) Diagenesis of Fe and $S$ in Amazon inner shelf muds: Apparent domination of $\mathrm{Fe}$ reduction and implications for the genesis of ironstones. Continental Shelf Res. 6, 263-289.

BanAT I. M. and NeDWell D. B. (1984) Inhibition of sulfate reduction in anoxic marine sediment by group VI anions. Estuar. Shelf Sci. 18, 36!-366.

Banat I. M., Nedwel.l. D. B. and Tal.antbalba M. (1983) Stimulation of methanogenesis by slurries of saltmarsh sediment after the addition of molybdate to inhibit sulfate-reducing bacteria. $J$. Gen. Microbiol. 129, 123-129.

BERNER R. A. (1967) Thermodynamic stabilities of sedimentary iron sulfides. Amer. J. Sci. 265, 773-785.

BER.NER R. A. (1969) Migration of iron and sulfur within anaerobic sediments during early diagenesis. Amer. J. Sci. 267, 19-42. 
BERNER R. A. (1970) Sedimentary pyrite formation. Amer. J. Sci. 268, $1-23$.

BERNER R. A. (1980) Early Diagenesis: A Theoretical Approach. Princeton Univ. Press, 250p.

BERNER R. A., BALDWIN T. and HOLDREN G. R. (1979) Authigenic iron sulfides as paleosalinity indicators. J. Sediment. Petrol. 49, $1345-1350$.

BERNER R. A. and WESTRICH J. T. (1985) Bioturbation and the early diagenesis of carbon and sulfur. Amer. J. Sci. 285, 193-206.

BOUDREAU B. P. (1984) On the equivalence of nonlocal and radialdiffusion models for porewater irrigation. J. Mar. Res. 42, 731735.

BOUDREAU B. P. and CANFIELD D. E. (1988) A provisional diagenetic model for $\mathrm{pH}$ in anoxic porewaters: Application to the FOAM site. J. Mar. Res. 46, 429-455.

BRICKER O. P. and TROUP B. N. (1975) Sediment-water exchange in Chesapeake Bay. In Estuarine Research. I. Chemistry, Biology and the Estuarine System (ed. L. E. CRONIN). pp. 3-27. Academic Press.

BRomfield S. M. (1954) Reduction of ferric compounds by soil bacteria. J. Gen. Microbiol 10, 1-6.

BURDIGE D. J. and NEALSON K. H. (1986) Chemical studies of sulfidemediated manganese reduction. Geomicrobiol. J. 4, 361-387.

CANFIELD D. E. (1988) Sulfate reduction and the diagenesis of iron in anoxic marine sediments. Ph.D. dissertation, Yale University. 248p.

Canfield D. E., Raiswell R., Westrich J. T., Reaves C. M. and BENER R. A. (1986) The use of chromium reduction in the analysis of reduced sulfur in sediments and shales. Chem. Geol. 54, 149155.

CANFIELD D. E. and BERNER R. A. (1987) Dissolution and pyritization of magnetite in anoxic marine sediments. Geochim. Cosmochim. Acta 51, 645-659.

CHANTON J. P. and MARTENS (1985) The effects of heat and stannous chloride addition on the active distillation of acid volatile sulfide from pyrite-rich marine sediment samples. Biogeochemistry 1, 375383.

Chanton J. P., MARTEns C. S. and Goldhaber M. B. (1987) Biogeochemical cycling in an organic-rich coastal marine basin. 7 . Sulfur mass balance. oxygen uptake and sulfide retention. Geochim. Cosmochim. Acta 51, 1187-1200.

ChEster R. and HUGHes M. J. (1967) A chemical technique for the separation of ferromanganese minerals, carbonate minerals and adsorbed trace elements from pelagic sediments. Chem. Geol. 2 , 249-262.

CLINE J. D. (1969) Spectrophotometric determination of hydrogen sulfide in natural waters. Limnol. Oceanogr. 14. 454-458.

CRIL.L. P. M. and MARTENS C. S. (1987) Biogeochemical cycling in an organic-rich coastal basin. 6 . Temporal and spacial variations in sulfate reduction rates. Geochim. Cosmochim. Acra 51, 11751186.

DAvison W. (1979) Soluble inorganic ferrous complexes in natural waters. Geochim. Cosmochim. Acta 43, 1693-1696.

Elderfield H., MCCAFFERY R. J., LUEDTKE N., BENDER M. and TRUESDALL V. W. (1981) Chemical diagenesis in Narragansett Bay sediments. Amer. J. Sci. 281, 1021-1055.

EMERSON S., JacoBs L. and TEBo B. (1983) The behavior of trace metals in marine anoxic waters: Solubilities at the oxygen-hydrogen sulfide interface. In Trace Metals in Sea Water (eds. C. S. WONG, E. BOYLE, K. W. BRULAND, J. D. BURTON and E. D. GoldBerG), pp. 579-609. Academic Press.

EMERSON S., JAHNKE R. and HeGGie D. (1984) Sediment-water exchange in shallow estuarine sediments. J. Mar. Res. 42, 709730.

EMERY K. O. and Rittendurg S. C. (1952) Early diagenesis of California basin sediments in relation to origin of ore. Bull. Amer. Assoc. Petrol. Geol. 36, 735-806.

Françoss R. (1987) A study of sulfur enrichment in the humic fraction of marine sediments during early diagenesis. Geochim. Cosmochim. Acta 51, 17-27.

Froelich P. N., Klinkhammer G. P., Bender M. L., LuedtKe N. A., Heath G. R., Cullen D., Dauphin P., Hammond D. and HARTMAN B. (1979) Early oxidation of organic matter in pelagic sediments of the eastern equatorial Atlantic: Suboxic diagenesis. Geochim. Cosmochim. Acta 43, 1075-1090.

GOLDHABER M. B. and KAPLAN I. R. (1974) The sulfur cycle. In The Sea. Vol. 5 (ed. E. D. GOLDBERG), pp. 569-655. Wiley-Interscience.

Goldhaber M. B., Aller R. C., Cochran J. K., Rosenfeld J. K., MARTENS C. S. and BERNER R. A. (1977) Sulfate reduction, diffusion, and bioturbation in Long Island Sound sediments: Report from the FOAM group. Amer. J. Sci. 277, 193-237.

HaRrison W. D., MUSGRave: D. and REEBURGH W. S. (1983) A wave induced transport process in marine sediments. J. Geophys. Res. 88, 7617-7622.

HEATH R. G. and DYMOND J. (1977) Genesis and transformation of metalliferous sediments from the East Pacific Rise, Bauer Deep and central basin Nazca Plate. Geol. Soc. Amer. Bull. 88, 723733.

HiNES M. E. and JoNES G. E. (1985) Microbial biogeochemistry and bioturbation in the sediments of Great Bay, New Hampshire. Estuar. Coast. Shelf Sci. 20, 729-742.

HINES M. E., ORFM W. H., LyONS W. B. and JoNes G. E. (1982) Microbial activity and bioturbation-induced oscillations in porewater chemistry in spring. Nature 299, 433-435.

JAHNKE R. (1985) A model of microenvironments in deep-sea sediments: Formation and effects on porewater profiles. Limnol. Oceanogr. 30, 956-965.

JONES J. G. (1983) A note on the isolation and enumeration of bacteria which deposit and reduce ferric iron. J. Appl. Bacteriol. 54, 305310

JONES J. G., GARDNER S. and SIMON B. M. (1983) Bacterial reduction of ferric iron in a stratified eutrophic lake. J. Gen. Microbiol. 129, $131-139$.

JøRGENSEN B. B. (1977a) Bacterial sulfate reduction within reduced microenvironments of oxidized marine sediments. Mar. Biol. 41, $7-17$.

JøRGENSEN B. B. (1977b) The sulfur cycle of a coastal marine sediment (Limfjorden, Denmark). Limnol. Oceanogr. 5, 814-832.

JøRGENSEN B. B. (1978a) A comparison of methods for the quantification of bacterial sulfate reduction in coastal marine sediments. I Measurement with radiotracer techniques. J. Geomicrobiol. 1, 11-27.

JøRGENSEN B. B. (1978b) A comparison of methods for the quantification of bacterial sulfate reduction in coastal marine sediments. III Estimation from chemical and bacteriological field data. $J$. Geomicrobiol. 1, 49-64.

KARIIN R. LFVI R. and LEVI S. (1985) Geochemical and sedimentolagical control of the magnetic properties of hemipelagic sediments. J. Geophys. Res. 90, 10373-10392.

Krishnaswam! S., Moniaghan M. C., Westrich J. T., Bennett J. T. and TURFKIAN K. K. (1984) Chronologies of sedimentary processes in sediments of the FOAM site, Long Island Sound, Connecticut. Amer. J. Sci. 284, 706-733.

LINDSTROM C. H. M. (1980) Transformations of iron diagenesis during early diagenesis. In sifu studies of a Baltic Sea sedimentwater interface. Contrib. Microbial Geochem., Dept. of Geology, Univ. of Stockholm, 162p.

LORD C. J. III and CHURCH T. M. (1983) The geochemistry of salt marshes: Sedimentary ion diffusion, sulfate reduction, and pyritization. Geochim. Cosmochim. Acta 47, 1381-1391.

LOVLEY D. R. and PHILLIPS E. J. (1986a) Organic matter mineralization with reduction of ferric iron in anaerobic sediments. Appl. Environ. Microbiol. 51, 683-689.

LOVI.EY D. R. and PHILLIPS E. J. (1986b) Availability of ferric iron for microbial reduction in bottom sediments of the freshwater tidal Potomic River. Appl. Environ. Microbiol. 52, 7511-757.

MARTENS C. S., BerNer R. A. and Rosenfeld J. K. (1978) Interstitial water chemistry of anoxic Long Island Sound sediments. 2. Nutrient regeneration and phosphate removal. Limnol. Oceanogr. 23, 605-617.

MLNCH J. C. and OTTOW J. C. G. (1982) Effect of cell contact and iron (III) oxide form on bacterial iron reduction. $Z$. Pflanz. Dungung Boden. 145, 66-77. 
MurRay J. W., Grundmanis V. and SMethie W. M. (1978) Interstitial water chemistry in the sediments of Saanich inlet. Gea chim. Cosmochim. Acta 42, 1011-1026.

NissenbaluM A and KAPI.AN I. R. (1972) Chemical and isotopic evidence for in silu origin of marine humic substances. Limnol. Oceanogr. 17, 570-582.

OREMLAND R. S. and TAYLOR B. F. (1978) Sulfate reduction and methanogenesis in marine sediments. Geochim. Cosmochim. Acta 42, 209-214.

Pelczar M. J. and Reid R. D. (1965) Microbiology: MoGraw Hill, $602 p$

PYZIK A. J. and SOMMER S. E. (1981) Sedimentary iron monosulfides: Kinetics and mechanism of formation. Geachim. Cosmochim. Acta 45, 687-698.

RAISWELL R. and BERNER R. A. (1985) Pyrite formation in euxinic and semi-euxinic sediments. Amer. J. Sci. 285, 710-724.

SAleh A. M., MACPHerson R. M. and Miller J. D. A. (1964) The effect of inhibitors on sulfate reducing bacteria: A compilation. $J$ Appl. Microbiol. 27, 281-293.

SChwERTMANN U. and ThalmaN H. (1976) The influence of [Fe(111)], [Si] and $\mathrm{pH}$ on the formation of lepidocrocite and ferrihydrite during oxidation of aqueous $\mathrm{FeCl}_{2}$ solutions. Clay Mineral. 11, 189-220.

SCHWERTMANN U. and MURAD E. (1983) Effect of pH on the formation of goethite and hematite from ferrihydrite. Clays Clay Mineral. 31, 277-284.

SHOKES R. F. (1976) Rate-dependent distributions of ${ }^{210} \mathrm{~Pb}$ and interstitial sulfate in sediments of the Mississippi Delta. Ph.D. dissertation, Texas A\&M, 122p.

SPYRENSEN J. (1982) Reduction of ferric iron in anaerobic, marine sediment and interaction with reduction of nitrate and sulfate. Appl. Environ. Microbiol. 43, 319-324.

STOOKEY L. L. (1970) Ferrozine- a new spectrophotometric reagent for iron. Anal. Chem. 42, 779-781.

STUMM W. and MORGAN J. J. (1981) Aquatic Chemistry, 2nd edn. J. Wiley \& Sons, 780p.

SUNDBY B. and Silverberg N. (1985) Manganese fluxes in the benthic boundry layer. Limnol. Oceanogr. 30, 372-381.

Tessier A., Cambell P. G. C. and Bisson M. (1979) Sequential extraction procedure for the speciation of particulate trace metals. Anal. Chem. 51, 844-851.

Trefry J. H. and Presley B. J. (1982) Manganese fluxes from Mississippi Delta sediments. Geochim. Cosmochim. Acta 46, 17151726.

TUGel J. B., HiNes M. E. and Jones G. E. (1986) Microbial iron reduction by enrichment cultures isolated from estuarine sediments. Appl Environ. Microbiol. 52, 1167-1172.

VANDERBORGHT J. P., WOLLAST R. and BILLEN G. (1977) Kinetic models of diagenesis in disturbed sediments. Part 1. Mass transfer properties and silica diagenesis. Limnol. Oceanogr. 22, 787-793.

WESTRICH J. T. (1983) The consequences and controls of bacterial sulfate reduction in marine sediments. Ph.D. dissertation, Yale Univ., 530p.

ZHABINA N. N. and VolkoV I. I. (1978) A method of determination of various sulfur compounds in sea sediments and rocks. In Environmental Biogeochemistry: Methods, Metals and Assessment (ed. W. E. Krumbein), Vol. 3, pp. 735-745. Ann Arbor Science Publishers, Ann Arbor, MI.

\begin{tabular}{|c|c|c|c|c|c|c|c|}
\hline \multicolumn{8}{|c|}{ FOAM Solid Phase Iron ${ }^{a b} b$} \\
\hline $\begin{array}{l}\text { Depeh } \\
(\mathrm{cm})\end{array}$ & $\begin{array}{c}\text { Oxalase } \\
\mathrm{Fe}\end{array}$ & $\begin{array}{l}\text { Dithion. } \\
\text { Fe }\end{array}$ & $\underset{\text { Fe }}{\text { Pyrite }}$ & $\begin{array}{c}\text { AVS } \\
\mathrm{Fe}\end{array}$ & $\begin{array}{c}\text { Total } \\
\mathrm{Fe}\end{array}$ & $A^{C}$ & $\mathrm{Bd}^{\mathrm{d}}$ \\
\hline $\begin{array}{c}0-2 \\
2-4 \\
4-6 \\
6-9 \\
9-12 \\
\text { Susped. }\end{array}$ & $\begin{array}{l}0.134 \\
0.115 \\
0.104 \\
0.0783 \\
0.0625\end{array}$ & $\begin{array}{l}0.230 \\
0.185 \\
0.138 \\
0.0733 \\
0.0625\end{array}$ & $\begin{array}{l}0.171 \\
0.348 \\
0.491 \\
0.528 \\
0.622\end{array}$ & $\begin{array}{l}0.065 \\
0.084 \\
0.098 \\
0.065 \\
0.058\end{array}$ & $\begin{array}{l}2.22 \\
2.79 \\
3.17 \\
3.18 \\
3.25\end{array}$ & $\begin{array}{l}0.069 \\
0.031 \\
0.006 \\
0.0133 \\
0.0045\end{array}$ & $\begin{array}{c}0.096 \\
0.070 \\
0.030 \\
0 \\
0\end{array}$ \\
\hline Sed. & 0.393 & 0.573 & $0.228^{e}$ & $N A^{f}$ & 3.34 & 0.393 & 0.180 \\
\hline $\begin{array}{l}\text { a trom } \\
\text { b all con } \\
\text { c "easily } \\
\text { d "crysta } \\
e_{\text {this im }} \\
\text { sulfur } \\
\text { as pyr }\end{array}$ & $\begin{array}{l}\text { Shen-term } \\
\text { ncentration } \\
\text { yextractub } \\
\text { alline" Fe } \\
\text { on content } \\
\text { value of } \mathrm{C} \\
\text { rite. } \\
\text { alyzed, bu }\end{array}$ & $\begin{array}{l}\text { unamended } \\
\text { is in wr\% } \\
\text { le" Fe = oxa } \\
\text { oxides = dit } \\
\text { is calculaie }\end{array}$ & ditate-A & $\begin{array}{l}\text { int incuba } \\
\text { is } \\
\text { oxalate } \\
\text { measure }\end{array}$ & n & V. & ent \\
\hline
\end{tabular}

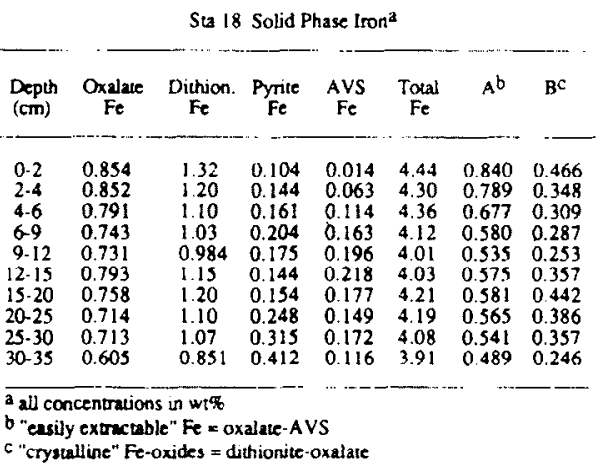

\begin{tabular}{|c|c|c|c|c|c|c|c|}
\hline \multirow[b]{2}{*}{$\begin{array}{l}\text { Depph } \\
(\mathrm{cm})\end{array}$} & \multicolumn{6}{|c|}{ Su 19 Solid Phase Iron } & \multirow{2}{*}{$\mathrm{BC}^{\mathrm{C}}$} \\
\hline & $\begin{array}{c}\text { Oxalate } \\
\mathrm{Fe}\end{array}$ & $\begin{array}{l}\text { Dithion. } \\
\text { Fe }\end{array}$ & $\begin{array}{c}\text { Pyrice } \\
\text { Fe }\end{array}$ & $\underset{\mathrm{AVS}}{\mathrm{Fe}}$ & $\begin{array}{c}\text { Total } \\
\mathrm{Fe}\end{array}$ & $A^{b}$ & \\
\hline $\begin{array}{c}0.3 \\
3.6 \\
6-9 \\
9.15 \\
15.20 \\
20.30\end{array}$ & $\begin{array}{l}0.941 \\
0.928 \\
0.944 \\
0.891 \\
0.826 \\
0.847\end{array}$ & $\begin{array}{l}1.48 \\
1.43 \\
1.46 \\
1.38 \\
1.41 \\
1.34\end{array}$ & $\begin{array}{l}0.028 \\
0.033 \\
0.032 \\
0.045 \\
0.130 \\
0.081\end{array}$ & $\begin{array}{l}0.009 \\
0.026 \\
0.063 \\
0.121 \\
0.135 \\
0.156\end{array}$ & $\begin{array}{l}4.26 \\
4.24 \\
4.25 \\
4.38 \\
4.31 \\
4.39\end{array}$ & $\begin{array}{l}0.932 \\
0.895 \\
0.881 \\
0.770 \\
0.691 \\
0.691\end{array}$ & $\begin{array}{l}0.539 \\
0.502 \\
0.516 \\
0.489 \\
0.584 \\
0.493\end{array}$ \\
\hline
\end{tabular}

